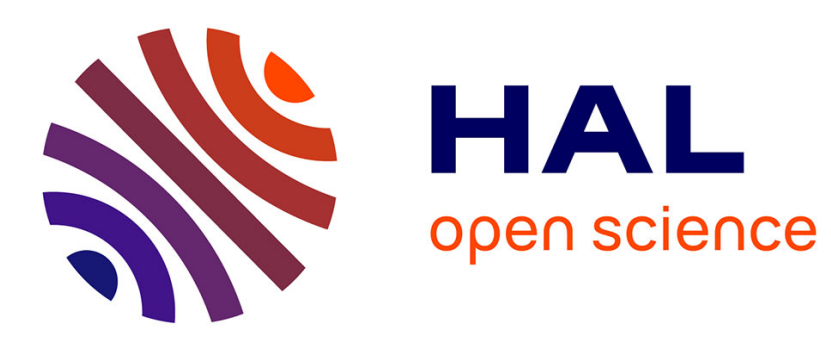

\title{
Spatiotemporal Patterning of Living Cells with Extracellular DNA Programs
}

Marc van Der Hofstadt, Jean-Christophe Galas, André Estévez-Torres

\section{To cite this version:}

Marc van Der Hofstadt, Jean-Christophe Galas, André Estévez-Torres. Spatiotemporal Patterning of Living Cells with Extracellular DNA Programs. ACS Nano, 2020, 10.1021/acsnano.0c09422 . hal03092416

\section{HAL Id: hal-03092416 https://hal.science/hal-03092416}

Submitted on 2 Jan 2021

HAL is a multi-disciplinary open access archive for the deposit and dissemination of scientific research documents, whether they are published or not. The documents may come from teaching and research institutions in France or abroad, or from public or private research centers.
L'archive ouverte pluridisciplinaire HAL, est destinée au dépôt et à la diffusion de documents scientifiques de niveau recherche, publiés ou non, émanant des établissements d'enseignement et de recherche français ou étrangers, des laboratoires publics ou privés. 


\title{
Spatio-Temporal Patterning of Living Cells with Extracellular DNA Programs
}

\author{
Marc Van Der Hofstadt, ${ }^{*}$ Jean-Christophe Galas, ${ }^{*}$ and André Estevez-Torres* \\ Sorbonne Université, CNRS, Institut de Biologie Paris-Seine (IBPS), Laboratoire Jean Perrin \\ (LJP), F-75005, Paris, France
}

E-mail: marcvdhs@gmail.com; jean-christophe.galas@upmc.fr; andre.estevez-torres@upmc.fr

\begin{abstract}
Reactive extracellular media focus on engineering reaction networks outside the cell to control intracellular chemical composition across time and space. However, current implementations lack the feedback loops and out-of-equilibrium molecular dynamics for encoding spatio-temporal control. Here, we demonstrate that enzyme-DNA molecular programs combining these qualities are functional in an extracellular medium where human cells can grow. With this approach, we construct an internalization program that delivers fluorescent DNA inside living cells and remains functional for at least $48 \mathrm{~h}$. Its non-equilibrium dynamics allows us to control both the time and position of cell internalization. In particular, a spatially inhomogeneous version of this program generates a tunable reaction-diffusion two-band pattern of cell internalization. This demonstrates that a synthetic extracellular program can provide temporal and positional information to living cells, emulating archetypal mechanisms observed during embryo development. We foresee that non-equilibrium reactive extracellular media could be advantageously applied to in vitro biomolecular tracking, tissue engineering or smart bandages.
\end{abstract}




\section{Keywords}

DNA nanotechnology, cell patterning, reactive extracellular media, growth medium, reactiondiffusion,

Traditionally, synthetic biology has focused its engineering efforts inside the cells, through the assembly of relatively complex intracellular genetic circuits. ${ }^{1}$ These circuits have been driven from the outside by using simple extracellular inputs (such as small molecules ${ }^{2,3}$ or light ${ }^{4}$ ), resulting, for instance, in the control of cellular fate ${ }^{5}$ and intracellular composition. ${ }^{6}$ A complementary route consists in designing a reactive extracellular medium to control the intracellular composition. Such strategy could be advantageously applied in tissue engineering ${ }^{7}$ or smart bandages, ${ }^{8}$ but also to better understand cells' behaviour in a changing environment. ${ }^{9}$

The reactive extracellular approach has been explored in the last decade with the tools of DNA nanotechnology and molecular programming. ${ }^{10}$ Indeed, extracellular DNA nanostructures have been used for delivering payloads in vitro ${ }^{11}$ and in vivo, ${ }^{12}$ for controlling cell adhesion, ${ }^{13}$ and for intracellular detection. ${ }^{14}$ In addition, nucleic acid molecular programs are able to classify cells depending on the biomarkers displayed on their surface ${ }^{15-17}$ and are functional inside cells. ${ }^{18,19}$ However, to our knowledge, these methods have not yet been able to dynamically control the composition of the extracellular medium in the presence of viable cells.

The design of reactive extracellular media has been pioneered by Mansy and co-workers using transcription-translation (TX-TL) reaction networks. ${ }^{20-23}$ In this approach, the extracellular reactive medium is protected from the cells inside liposomes and the interaction between the two happens through small molecules carried by transmembrane channels. The strength of this approach relies on the diversity of small molecules that may be used to 
entertain the conversation between synthetic and living cells. The limitation, in turn, is the relatively simple reaction dynamics that can be implemented by cell-free TX-TL networks. This is due to the rapid consumption of energy in the translation step, which rapidly drives the reaction to chemical equilibrium in a closed reactor. For this reason, out-of-equilibrium TX-TL reaction networks with feedback loops have only been observed in open reactors ${ }^{24,25}$ without cells. However, such non-equilibrium networks are key elements contributing to the complexity of living cells. They encode important behaviors such as bistability, homeostasis, temporal control and pattern formation but, to our knowledge, have not yet been observed in reactive extracellular media.

In this work, we have engineered a reactive medium that can support out-of-equilibrium reaction networks with feedbacks in the presence of living human cells. The reactive medium is based on DNA-enzyme molecular programs that autonomously control the concentration of selected chemicals which in turn modify the intracellular composition of living cells, both being regulated in time and space. Firstly, we demonstrate that an autocatalytic amplifier and a bistable switch are active and remain out of equilibrium for tens of hours in the presence of living human cells. In particular, this means that extracellular DNA can be detected among viable cells. Secondly, we show that these programs can trigger the internalization of fluorescently-labelled DNA and thus control the chemical composition of living cells. Importantly, its out-of-equilibrium dynamics allows the program to remain at steady state for $48 \mathrm{~h}$ and to encode a temporal control. Such temporal control can be triggered externally, by responding to external inputs, or internally, through a clock reaction that causes internalization at times that are chemically encoded. Finally, we demonstrate that a reactive extracellular medium processes the spatial information contained in a concentration gradient and transfers it to living cells, recapitulating a major mechanism of pattern formation in embryo development: ${ }^{26}$ a shallow extracellular gradient of DNA creates a sharp two-band pattern of fluorescent DNA that ultimately patterns living cells. 


\section{Results and Discussion}

\section{A common buffer for DNA programs and living cells}

The PEN DNA toolbox is a DNA programming framework that implements the three basic operations of regulatory networks - activation, repression and degradation — using short DNA oligonucleotides and 3 enzymes, namely a polymerase, an exonuclease and a nicking enzyme (PEN). The use of enzymes allows the implementation of non-equilibrium reaction networks with feedbacks ${ }^{27,28}$ that display robust ${ }^{29}$ dynamics, such as oscillations, ${ }^{27,30}$ bistability $^{31-33}$ and spatial patterns. ${ }^{34,35}$

Figure 1a depicts the core element of PEN networks used throughout this work: an autocatalytic module that exponentially amplifies an oligonucleotide $\mathbf{A}$, before reaching a steady state. Briefly, A is a single-stranded DNA (ssDNA), called trigger, and $\mathbf{T}$ is a ssDNA, called template, twice complementary to $\mathbf{A}$. Upon hybridization of $\mathbf{A}$ on the 3' end of $\mathbf{T}$, a polymerase enzyme elongates $\mathbf{A}$ until it forms a fully double-stranded DNA (dsDNA). A nicking enzyme cuts the elongated strand, generating two copies of $\mathbf{A}$, that dissociate from $\mathbf{T}$, and hence show exponential amplification through the net reaction $\mathbf{A} \rightarrow 2 \mathbf{A}$. Simultaneously, an exonuclease enzyme selectively degrades free $\mathbf{A}$ and, after some time, the equilibration of autocatalysis and degradation yields a steady state where the concentration of $\mathbf{A}$, noted $[\mathrm{A}]$, is constant and equal to $[\mathrm{A}]_{s s}$. This non-equilibrium steady state is maintained until the

deoxynucleotides (dNTPs) present in the solution are consumed, which takes several days. ${ }^{36}$ Our first objective was to find common experimental conditions where PEN autocatalysis was functional and cells were viable.

The majority of PEN autocatalytic modules operate between $42-45^{\circ} \mathrm{C}$ in an optimal buffer, ${ }^{37}$ hereafter referred as DNA buffer. Nevertheless, standard human cell culture conditions require $37{ }^{\circ} \mathrm{C}$ and a rich medium, such as Dulbecco's modified Eagle's medium (DMEM). We thus screened different buffer compositions and found a cell-DNA buffer compatible with both systems (SI Section 2 and Figures S1-S4). In addition, the sequences of 
$\mathbf{A}$ and $\mathbf{T}$ were redesigned to increase the autocatalytic efficiency at $37^{\circ} \mathrm{C}$ (SI Table S2 and Figure S5).

To assess the performance of the autocatalytic network in the new buffer, we first monitored its dynamics in the absence of cells. To do so, strand $\mathbf{T}$ had a yellow fluorophore attached to its 5' end that was quenched upon hybridization; the shift in fluorescence signal being proportional to $[\mathrm{A}]$ if $[\mathrm{A}]<[\mathrm{T}]_{0}$, where $[\mathrm{T}]_{0}$ is the initial concentration of $\mathbf{T} .{ }^{38}$ Figure $1 \mathrm{~b}$ shows that autocatalytic dynamics are qualitatively similar in the DNA and the cell-DNA buffers in the absence of cells, with a sigmoidal curve characteristic of PEN autocatalytic reactions. ${ }^{27}$

The amplification kinetics were 2-fold slower in the cell-DNA buffer, which we attribute to a lower efficiency of the enzymes (Figure S6). As expected, no reaction was detected in the absence of PEN enzymes. Importantly, the concentration of $\mathbf{A}$ at steady state was identical in both buffers: starting from $[\mathrm{A}]_{0}=0.5 \mathrm{nM}, \mathbf{A}$ reached $400 \mathrm{nM}$, a 800 -fold amplification, within 200 min (Figure S5).

We then measured the viability of living human cervix epithelial carcinoma cells (HeLa cell line) in the different buffers and in the presence or in the absence of the autocatalytic network. Trypan blue cell staining after $24 \mathrm{~h}$ revealed large mortality of the cells in the DNA buffer, while the mortality remained low and comparable in the cell-DNA and in the reference cell-buffer (Figure 1c). However, propidium iodide cell staining combined with flow cytometry (Figure 1d) showed that cells divided $\sim 4$-fold slower in the cell-DNA buffer than in the cell-buffer (doubling time of 61 and $17 \mathrm{~h}$, respectively). We account this to the presence of DTT that causes partial cell detachment (Figure S2) and transiently activates endoplasmic reticulum stress. ${ }^{39}$ Note that, to avoid well-known problems with DNA programs,${ }^{40}$ the cellDNA buffer did not contain serum. We thus anticipate that the cell-DNA buffer could be further optimized to increase cell growth rate by adding serum. In summary, cell growth was slower in the cell-DNA buffer but cell death was negligible for up to 3 days. 

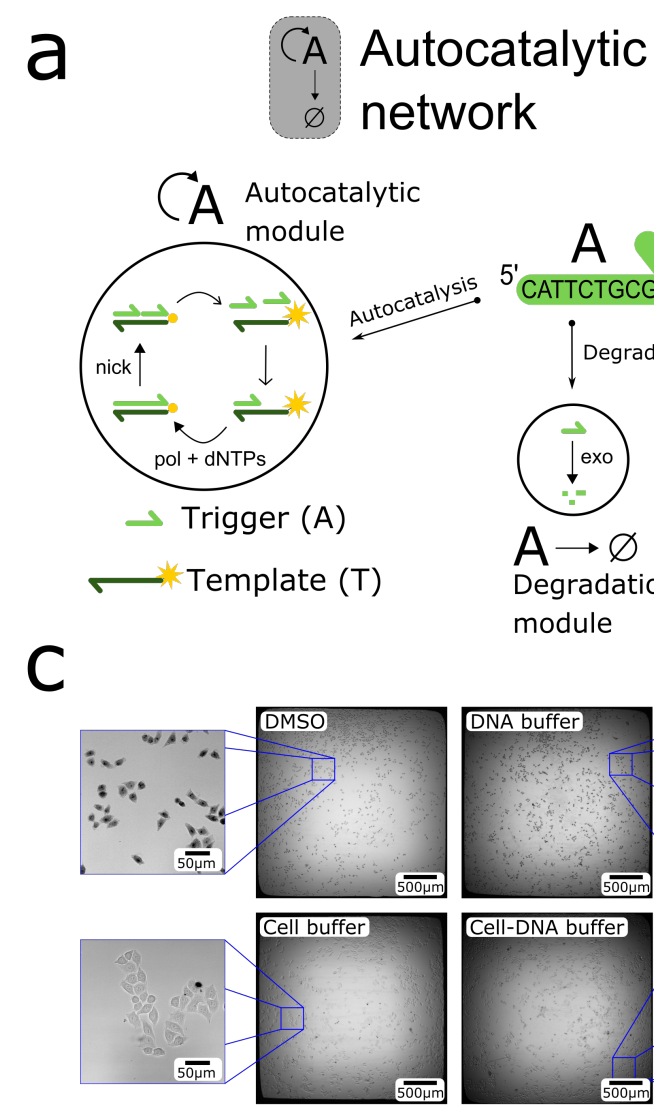

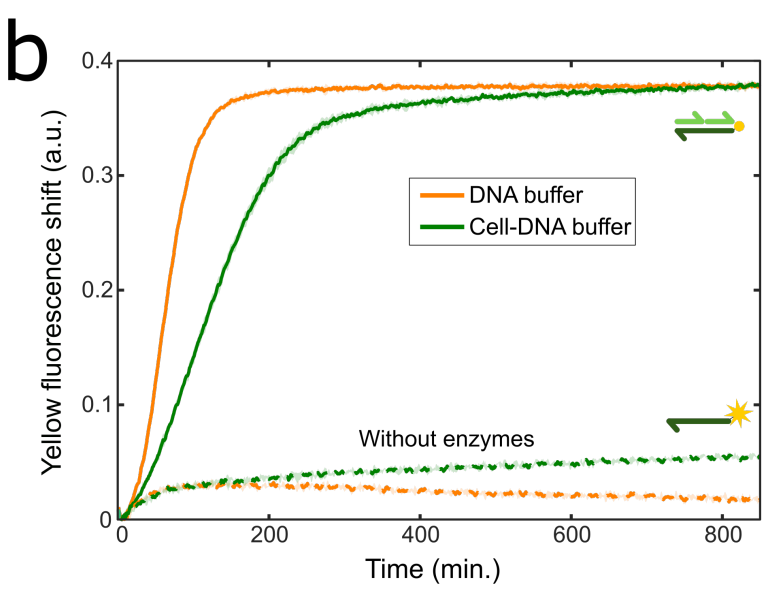

module

Figure 1: DNA autocatalysis is functional and cells are viable in a common buffer. a) Scheme of the core autocatalytic network used throughout this work, composed of an autocatalytic and a degradation module. ssDNAs are represented as harpoon-ended arrows. During autocatalysis, the trigger $\mathbf{A}$ replicates on template $\mathbf{T}$ through a combination of hybridization and dehybridization steps, elongation by a polymerase (pol), and cutting by a nicking enzyme (nick). Upon elongation of $\mathbf{A}$, the fluorescent marker attached to $\mathbf{T}$ (yellow star) gets quenched. Specific degradation of $\mathbf{A}$ is carried out by an exonuclease enzyme (exo). Solid and empty arrow-heads indicate irreversible and reversible reactions, respectively. b) Fluorescence shift from the fluorescently-labelled $\mathbf{T}$ versus time for the autocatalytic network in standard DNA buffer (orange line), or in the biocompatible cell-DNA buffer (green line), at $37^{\circ} \mathrm{C}$ in the absence of cells. Dashed lines correspond to negative controls in the absence of enzymes. The shades, corresponding to the standard deviation of a triplicate experiment, are of the order of the line thickness. c) Bright-field images of trypan blue-stained cells after $24 \mathrm{~h}$ incubation in different buffers, dead cells appear in black. Treatment with DMSO is a control for dead cells. The black halo around the central images is an optical artifact. d) Number of dead and live cells per well determined by propidium iodide staining and flow cytometry for different incubation times and conditions (experiment performed per triplicate and repeated 2 different days, $n=6$ ). In panels c and d the cell-DNA buffer contained the autocatalytic network. Conditions: $[\mathrm{A}]_{0}=0.5 \mathrm{nM},[\mathrm{T}]_{0}=100 \mathrm{nM}$ in panel b and $[\mathrm{A}]_{0}=20 \mathrm{nM},[\mathrm{T}]_{0}=200 \mathrm{nM}$ in $\mathrm{c}$ and $\mathrm{d}$. 


\section{An extracellular medium with out-of-equilibrium dynamics}

A key point of PEN reactions is the possibility to engineer out-of-equilibrium reaction networks with feedback loops. To demonstrate that this remains true in a solution containing living cells, we quantified the dynamics of two such networks in the cell-DNA buffer in the presence and in the absence of cells, using the DNA-buffer without cells as a positive control (see Methods).

Autocatalysis is the most basic feedback loop and it is essential to build out-of-equilibrium dynamics. ${ }^{41}$ Figure 2 a displays the amplification onset time, $\tau$, of the autocatalytic network as a function of the initial concentration of $\mathbf{A},[\mathrm{A}]_{0}$. In all three cases, $\tau$ depends linearly on $\log \left([\mathrm{A}]_{0}\right)$, indicating that autocatalysis followed first order kinetics. In addition, a moderate reduction in the rate of the autocatalytic reaction was observed: by $20 \%$ between the DNA and the cell-DNA buffer in the absence of cells and by a further $20 \%$ in the presence of living cells. Importantly, these data show that this DNA program was able to detect a specific DNA sequence at a concentration of $100 \mathrm{pM}$ in the presence of cells, within $300 \mathrm{~min}$.

Chemical bistability is intrinsically a non-equilibrium property. ${ }^{41}$ The PEN autocatalytic network can be reprogrammed into a bistable switch ${ }^{32}$ by adding a repressor strand $\mathbf{R}$, creating a reactive system with two antagonistic steady-states: an $O N$ state where autocatalysis of $\mathbf{A}$ occurs and $[\mathrm{A}]_{s s}$ is high, and an $O F F$ state, where the combined degradation of $\mathbf{A}$ by $\mathbf{R}$ and the exonuclease outcompetes autocatalysis, yielding $[\mathrm{A}]_{s s}=0$ (Figure $2 \mathrm{~b}$ ). Figure $2 \mathrm{c}$ shows the dynamics of the bistable switch in the presence of cells as a function of the concentration of $\mathbf{R}$, at constant $[\mathrm{A}]_{0}$. Increasing $[\mathrm{R}]_{0}$ slows down the exponential amplification of A until the system switches to the $O F F$ state at $[R]_{0}>40 \mathrm{nM}$, where no amplification was detectable within $850 \mathrm{~min}$. The plot of $\tau$ as a function of $[\mathrm{R}]_{0}$ highlights a strong non-linear

response that is characteristic of a bifurcation point (Figure 2d). Again, the presence of the cells does not qualitatively change the dynamics of the bistable switch in the cell-DNA buffer. Gel electrophoresis analysis confirmed that the bistable switch produced the same products in the presence and in the absence of cells (Figure 2e), with a similar pattern to 
the one previously obtained in standard conditions. ${ }^{29}$
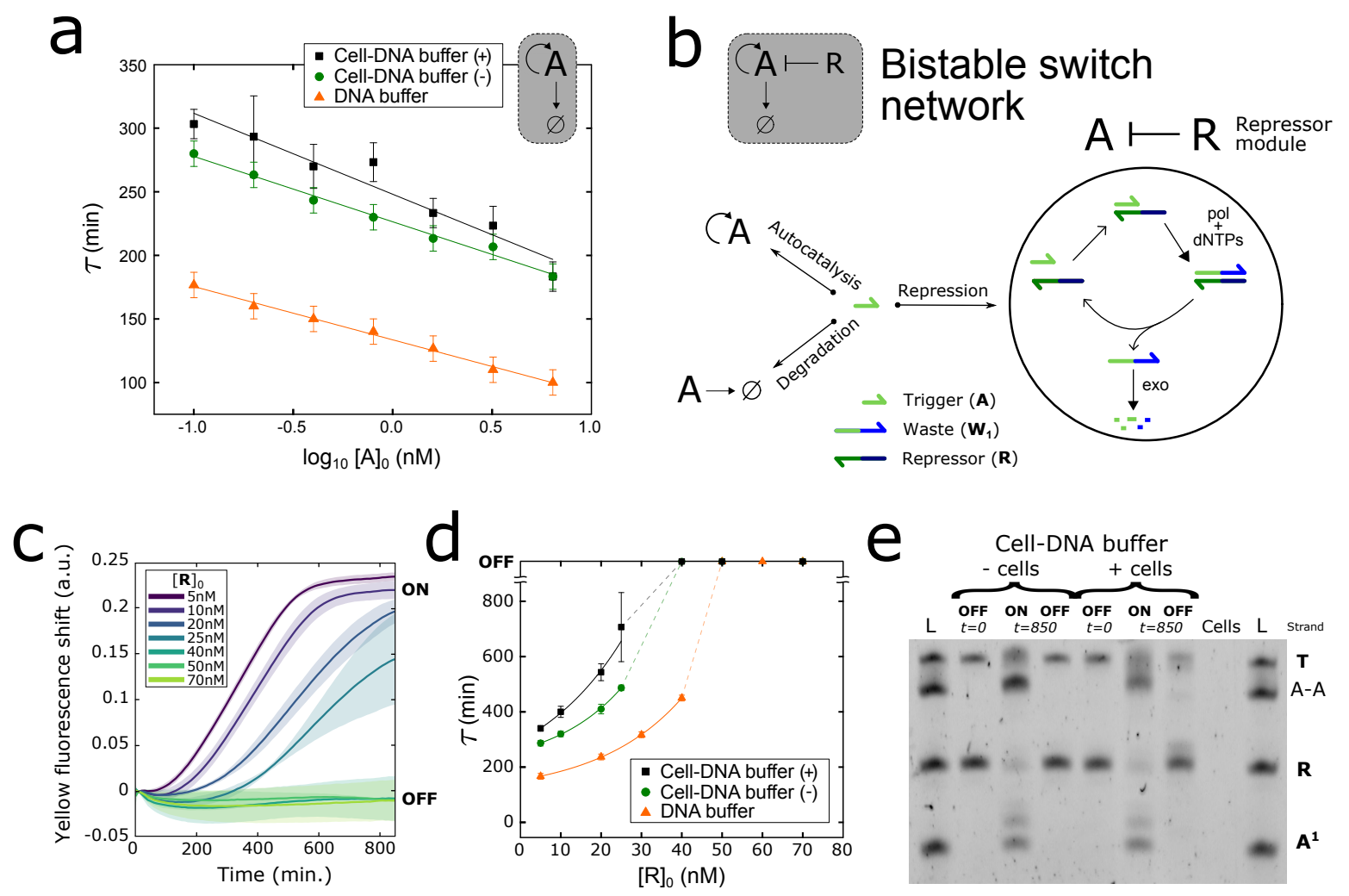

Figure 2: Out-of-equilibrium networks with feedbacks are fully functional in the presence of cells. a) Amplification onset time, $\tau$, against the decimal logarithm of the initial concentration of $\mathbf{A}$ for the autocatalytic network in two different buffers, and in the presence $((+)$, black squares $)$ or in the absence $((-)$, green circles $)$ of cells. Note that at large $[\mathrm{A}]_{0}$, the green and black symbols superimpose. b) A bistable switch (in gray) is obtained when the autocatalytic network is combined with a repressor module, where $\mathbf{A}$ binds to repressor $\mathbf{R}$ and is converted into a non-functional ssDNA, waste $\mathbf{W}_{\mathbf{1}}$, that is degraded by the exonuclease. c) Fluorescent shift from fluorescently-labelled $\mathbf{T}$ versus time for the bistable switch in the cell-DNA buffer in the presence of cells for increasing concentrations of $\mathbf{R},[R]_{0} . \mathrm{d}$ ) $\tau$ versus $[\mathrm{R}]_{0}$ for the bistable switch in the same conditions as in panel a. Data determined from panel c and Figure S7. e) Denaturing polyacrylamide gel electrophoresis showing the products obtained in the $O F F$ and $O N$ states of the bistable switch in the absence (-) or in the presence $(+)$ of cells, at different times. L is a ladder containing the template $\mathbf{T}$ (20 nt with a JOE fluorescent label), the strand A-A (a 22 nt resulting from the elongation of $\mathbf{A}$ on $\mathbf{T}$ ), repressor $\mathbf{R}$ (15 nt) and species $\mathbf{A}^{1}$ (which corresponds to species $\mathbf{A}$ with a phosphate group). The 'cells' lane is an extract from a solution containing cells only. Experiments were performed in 384-well cell culture plates. The error bars and the shades in panels a, c and $\mathrm{d}$ correspond to one standard deviation of a triplicate experiment. Solid lines in panels a and $\mathrm{d}$ are linear and exponential fits, respectively, while dashed lines are guides to the eye. Conditions: $[\mathrm{T}]_{0}=100 \mathrm{nM}$ in all panels, and $[\mathrm{A}]_{0}=0.5 \mathrm{nM}$ in panels $\mathrm{c}$ and $\mathrm{d}$. 


\section{A reactive medium that controls cellular internalization}

Until now we have shown the coexistence of two orthogonal out-of-equilibrium systems: the cells and the DNA programs. We now explore the possibility of engineering out-ofequilibrium DNA programs that alter the chemical composition of living cells. To do so, we created an internalization switch by coupling the bistable switch to the conversion module $\mathbf{A} \rightarrow \mathbf{S}$, that releases fluorescently-labeled ssDNA signal $\mathbf{S}$, later internalized by the cells (Figure 3a). The conversion module relies on the reaction $\mathbf{A}+\mathbf{C} \rightarrow \mathbf{S}+\mathbf{W}_{\mathbf{2}}$, where complex $\mathbf{C}$ is a partially double-stranded DNA whose shorter top strand is $\mathbf{S}$ and whose longer bottom strand (D) is attached to a hydrogel bead to avoid uncontrolled internalization, hereafter termed conversion bead. A is designed to bind to the bottom strand of complex $\mathbf{C}$ and release the top strand $\mathbf{S}$ by polymerase-assisted strand displacement into the extracellular medium. Once in solution, $\mathbf{S}$ is passively internalized by living cells ${ }^{42}$ within $2-4$ hours, making them fluorescent (SI Video S1 and Figure S8). Figure 3b sketches the experimental setup, where the cells and the conversion beads were placed in the bottom of a cell culture well filled with a reactive medium containing the cell-DNA buffer and the bistable switch. The beads were homogeneously distributed among the well's bottom and covered $2.6 \%$ of its surface (SI Figure S9).

The conversion beads are reminiscent of the liposomes used by Mansy and coworkers to protect TX-TL networks. ${ }^{20,22}$ However, here only the signal strand is physically separated from the cells while the other reactive components freely float in the medium. PEN reactions on hydrogel beads where also described by Gines et al. ${ }^{43}$ Note that our implementation is slightly different as it concerns a polymerase-assisted strand-displacement reaction which is a combination of PEN with DNA strand displacement ${ }^{44}$ reactions. 

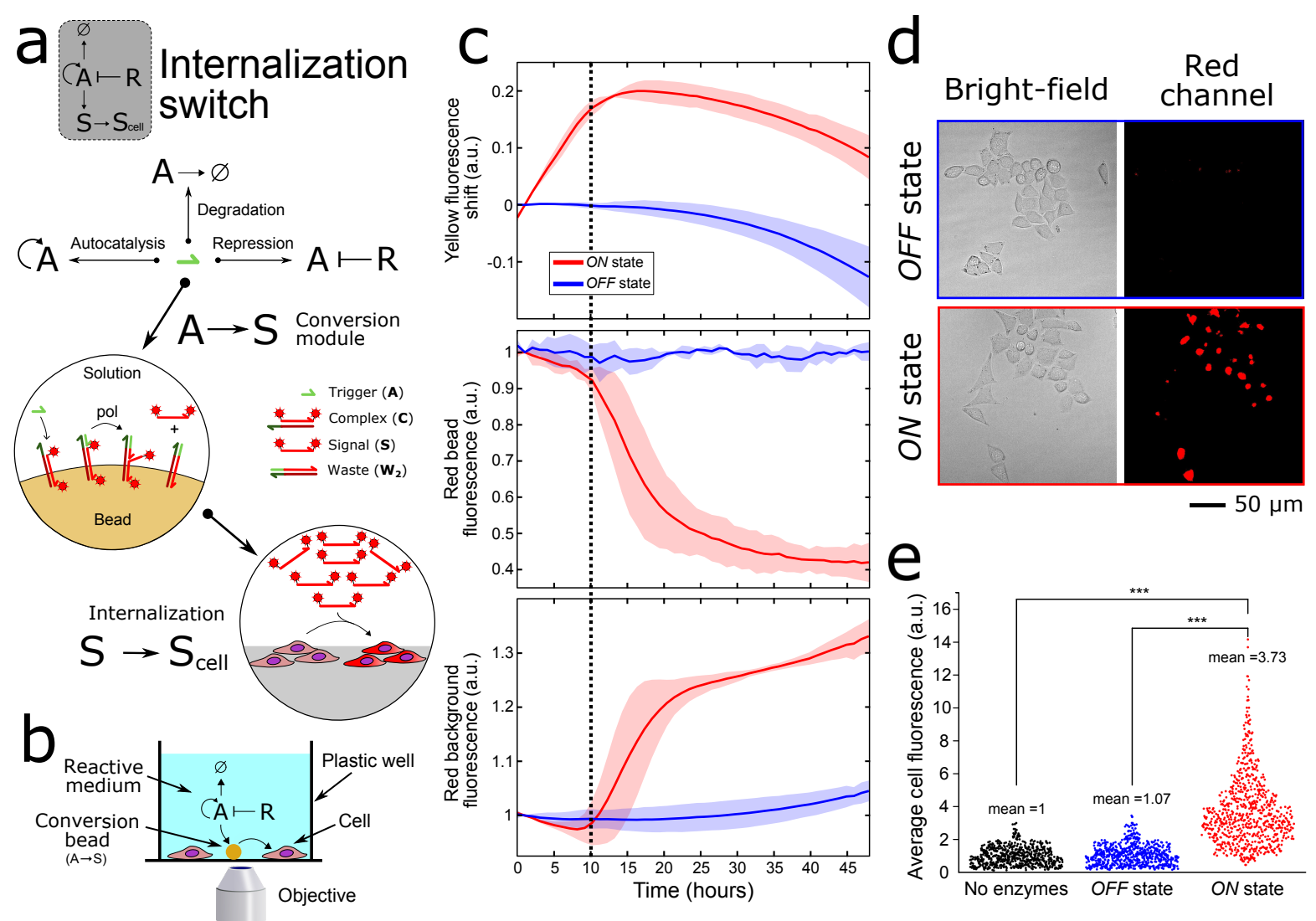

Figure 3: A reactive medium that controls the internalization of fluorescent DNA inside living cells. a) Scheme describing the operation of the DNA internalization switch embedded in the reactive medium. The gray box depicts the topology of the reaction network, composed of a bistable switch and a conversion module. In the conversion module, free $\mathbf{A}$ binds to complex $\mathbf{C}$, attached to hydrogel beads, and is elongated by the polymerase. This causes the release of the red fluorescent strand $\mathbf{S}$ into the solution, that can be passively internalized by the cells $\left(\mathbf{S}_{\text {cell }}\right)$. Red stars indicate attached red fluorophores. b) Cartoon of the experimental setup (not to scale). The cells are cultured in a reactive medium containing the bistable switch in solution and the conversion module attached to hydrogel beads of $34 \mu \mathrm{m}$ diameter. c) Fluorescence versus time plots displaying the dynamics of the internalization switch in the $O N$ (red line) and OFF (blue line) states in the presence of cells: production of $\mathbf{A}$ (top) and release of $\mathbf{S}$ from the beads (middle) into the solution (bottom). The black dashed line is a guide to the eye. d) Overlapping bright-field and red fluorescence microscopy images of living cells rinsed after being cultured for $48 \mathrm{~h}$ in the reactive medium in the $O F F$ and $O N$ state. e) Quantitative analysis of the average red fluorescence intensity per cell for cells cultured in the reactive medium in the absence of enzymes (black dots), in the OFF state (blue dots), and in the $O N$ state (red dots). At least 649 cells were analysed in each condition. Experiments were performed in 384-well culture plates in duplicates and repeated 3 different days (6 experiments in total). The shade in panel c corresponds to one standard deviation. Conditions: $[\mathrm{A}]_{0}=20 \mathrm{nM},[\mathrm{T}]_{0}=200 \mathrm{nM}$. The $O N$ and $O F F$ states correspond to $[R]_{0}=0$ and $200 \mathrm{nM}$, respectively. 
The conversion module was designed such that $\mathbf{A}$ hybridized to $\mathbf{C}$ less favourably than both to $\mathbf{T}$ and $\mathbf{R}$, and thus $\mathbf{S}$ was released only when the bistable switch was $O N$ and $[\mathrm{A}]$ was high (SI Figure S10). This second non-linearity makes the network particularly robust, as we will see below. Figures 3c and S11 show the dynamics of production of $\mathbf{A}$ and release of $\mathbf{S}$ in the medium for the internalization switch in the presence of cells in the $O N$ and OFF states. In the $O N$ state, $\mathbf{A}$ is amplified during at least $10 \mathrm{~h}$, when it saturates $\mathbf{T}$ and causes its fluorescent signal to reach a maximum before decreasing slowly. This indicates that at $t=10 \mathrm{~h},[\mathrm{~A}] \approx 2[\mathrm{~T}]_{0}=400 \mathrm{nM}$ in the medium, a 20 -fold amplification. At this point, there was enough free $\mathbf{A}$ to trigger the conversion reaction, releasing $\mathbf{S}$ from the beads into the extracellular medium. This process resulted in, respectively, a decrease and an increase in the red fluorescence of the conversion beads and the medium, and took another $10 \mathrm{~h}$. In contrast, in the $O F F$ state, no amplification of $\mathbf{A}$ was observed and the release of $\mathbf{S}$ in the medium was negligible after $20 \mathrm{~h}$ and was at least 8-fold lower after $48 \mathrm{~h}$. Note that the initial concentration of $\mathbf{A}(20 \mathrm{nM})$ would be sufficient for the polymerase to convert the total quantity of $\mathbf{C}$ in the well $(18 \mathrm{nM})$ into $\mathbf{S}$, but this release did not occur until [A] was high due to the non-linearity in the conversion module described above. Moreover, the evaporation of the medium was significant during this $48 \mathrm{~h}$-long experiment (30\%). This could explain the long-term decrease and increase of the fluorescent signals used to follow $\mathbf{A}$ and $\mathbf{S}$ in the medium (SI Figure S12) but did not compromise the function of the DNA program.

After $48 \mathrm{~h}$, the cells were rinsed to eliminate the excess of free $\mathbf{S}$ in the medium and imaged. Figure 3d shows that only the cells cultured in the presence of the internalization switch in the $O N$ state appear fluorescent. Higher magnification images (SI Figure S13) revealed an internalization into dot and rod-like compartments, which is compatible with an accumulation in mitochondria as observed for cyanine fluorophores ${ }^{45}$ similar to the one attached to $\mathbf{S}$. We observed that cells became fluorescent only when $\mathbf{S}$ was labelled with certain fluorophores and not others (Figure S14). Figure 3e displays the distribution of the average fluorescent intensity per cell, demonstrating that the $O N$ state results in a rate 
of cell internalization significantly different from the OFF state (two-tailed Mann-Whitney

$\mathrm{U}$ test, $p$-value $<0.001$ ), with, respectively, means of 3.7 and 1.1 , medians of 3.3 and 1.0 and standard deviations of 2.13 and 0.62 . A negative control in the absence of enzymes produced a distribution of cellular fluorescence not significantly different to the $O F F$ state, showing that the concentration of the red fluorophore inside the cells is controlled by the DNA program.

\section{The extracellular medium controls the timing of internalization}

Since the bistable switch is maintained out of equilibrium, it should be possible to turn its $O F F$ state $O N$ and hence trigger internalization at different times. This timing could be either externally triggered or pre-programmed in the reactive medium.

To test triggered internalization, we added either a ssDNA activator $\mathbf{R}^{*}$, or a random sequence to the $O F F$ state. $\mathbf{R}^{*}$ is complementary to $\mathbf{R}$ and, upon hybridization, it reduces $[\mathrm{R}]$, and hence switches the system to the $O N$ state. Note that $\mathbf{R}^{*}$ binds in a reversible manner to $\mathbf{R}$ at $37^{\circ} \mathrm{C}$, so we used a 4.5 -fold excess of $\mathbf{R}^{*}$ to shift the equilibrium towards the hybridization of $\mathbf{R}^{*}$ with $\mathbf{R}$. Figures $4 \mathrm{a}-\mathrm{b}$ and $\mathrm{S} 15$ show the response of the internalization switch when $\mathbf{R}^{*}$ or a random sequence was introduced $6 \mathrm{~h}$ after the beginning of the experiment, together with controls for the $O N$ and $O F F$ states. The switch worked as expected. No significant difference was observed in the $O F F$ state after the addition of the random sequence. In contrast, the addition of $\mathbf{R}^{*}$ switched on the autocatalysis, which further caused the release of $\mathbf{S}$, with delays of $16 \mathrm{~h}$ and $13 \mathrm{~h}$, respectively, compared to the $O N$ state. As anticipated, only the cells where the DNA activator was introduced internalized the fluorescent strand $\mathbf{S}$ (Figure $4 \mathrm{~b}$ ) (two-tailed Mann-Whitney $\mathrm{U}$ test, $p$-value $<0.001$ ), showing that the reactive extracellular medium was responsive for at least $6 \mathrm{~h}$, and was able to change cellular composition for up to $48 \mathrm{~h}$ of cell culture. 

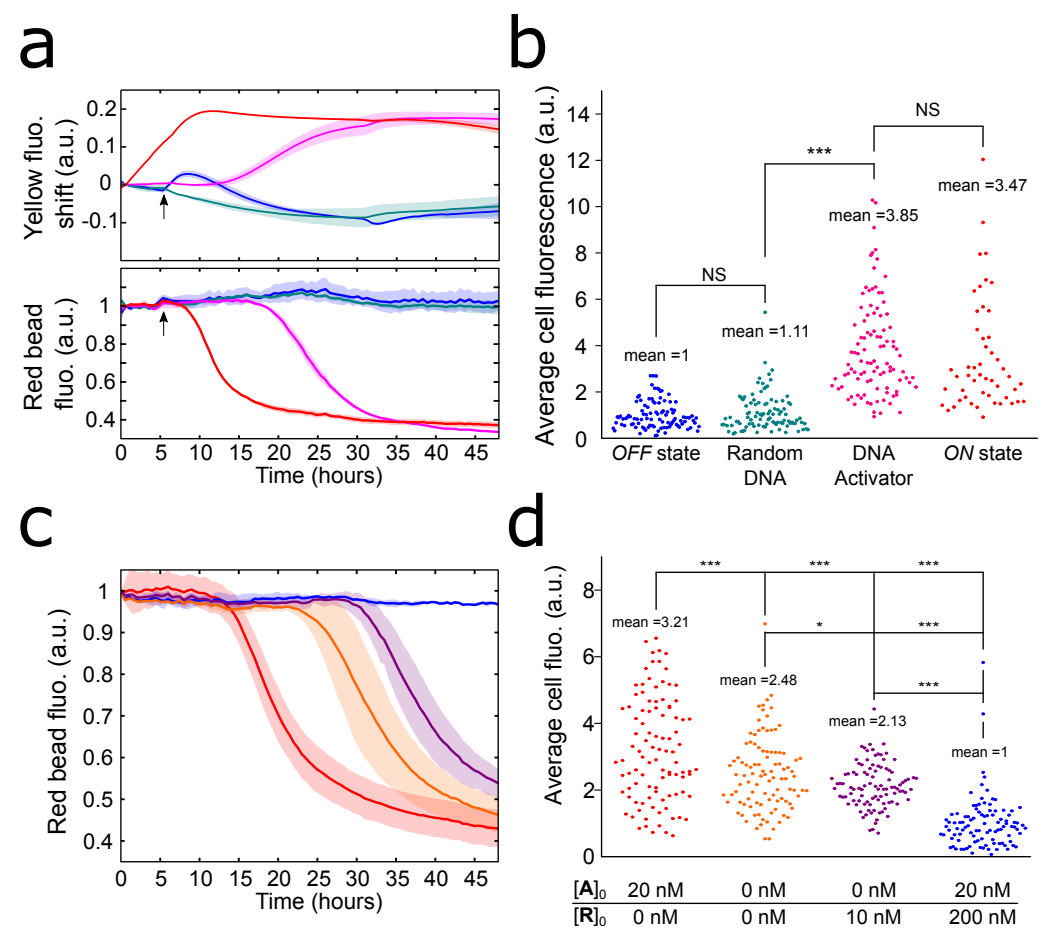

Figure 4: The extracellular medium controls the internalization time and the amount of $\mathbf{S}$ delivered to the cells. a) Fluorescence versus time plots showing the dynamics of production of $\mathbf{A}$ (top) and the release of $\mathbf{S}$ from the beads (bottom) in the presence of cells. The curves show the unperturbed $O N$ (red) and $O F F$ (blue) states, as well as $O F F$ states where a ssDNA, either $\mathbf{R}^{*}$ (pink) or a random sequence (teal), was introduced at $t=6 \mathrm{~h}$ (indicated with an arrow). The bump is an artifact of the addition step. b) Quantitative analysis of the average red fluorescence intensity of living cells after $48 \mathrm{~h}$ exposure to the conditions in panel a $(n=50)$. Fluorescence versus time plots showing the release of $\mathbf{S}$ from the beads (c) and the resulting average red fluorescence intensity of living cells after $48 \mathrm{~h}(\mathrm{~d})$ for different preprogrammed dynamics of the reactive medium. Each color corresponds to different initial concentrations of $\mathbf{A}$ and $\mathbf{S}$ as indicated in the bottom of panel d. 100 cells were measured for each condition in panel $\mathrm{d}$. The shade in panels a and c correspond to one standard deviation of a duplicate experiment performed on the same day. NS: Not significant. Conditions for panel a and b: $[\mathrm{A}]_{0}=20 \mathrm{nM},[\mathrm{T}]_{0}=200 \mathrm{nM}$. The $O N$ and $O F F$ states correspond to $[\mathrm{R}]_{0}=0$ and $200 \mathrm{nM}$, respectively and ssDNAs were added at $900 \mathrm{nM}$. Conditions for panel $\mathrm{c}$ and $\mathrm{d}:[\mathrm{T}]_{0}=200 \mathrm{nM}$.

The bistable switch can also be used as a clock reaction that triggers the release of $\mathbf{S}$ at a pre-encoded time. To do so we tuned the kinetics of destabilization of the OFF state by changing the initial concentrations of $\mathbf{A}$ and $\mathbf{R}$ (Figures 4c and d, and S16). Depending on the initial conditions, the timing of the release of $\mathbf{S}$ from the beads could be adjusted between 13 and $30 \mathrm{~h}$. Importantly, this delay was controlled independently from the kinetics 
of the release step, that remained unchanged. By delaying the release, we expect to decrease the effective concentration of the red fluorescent strand $\mathbf{S}$ at which the cells are exposed. Figure $4 \mathrm{~d}$ shows that the higher the delay of the fluorescent release, the lower the average cell fluorescence measured after 48 h (two-tailed Mann-Whitney U test, $p$-value $<0.05$ or $<0.001$ ), indicating that the amount of $\mathbf{S}$ inside the cell can be pre-encoded in the reactive medium.

The internalization of oligonucleotides inside cells is a notoriously complex process. ${ }^{46,47}$ It strongly depends on the cell type, on the oligonucleotide chemical modifications and on the composition of the extracellular medium. As a result, we cannot rule out that strands $\mathbf{A}$, $\mathbf{T}$ and $\mathbf{R}$, that are free in solution, may be internalized to some extent. However, our results demonstrate that the fraction of internalization for those strands is negligible when measured by gel electrophoresis (Figure 2e). In addition, PEN enzymes may also be internalized but the correct behavior of the reactive switch $30 \mathrm{~h}$ after the start of the experiment (Figure 4c) suggests that this does not significantly deplete the enzymes.

Finally, note that the $48 \mathrm{~h}$ duration of the experiments was mainly limited by evaporation during long-term cell culture under the microscope. In particular, within $48 \mathrm{~h}$ we do not expect the non-equilibrium state of the reactive solution to be limited by the dNTPs concentration. ${ }^{36}$

\section{The extracellular medium provides positional information to the cells}

Another characteristic property of out-of-equilibrium reactions with feedbacks is their ability to give rise to spatial concentration patterns via reaction-diffusion mechanisms. ${ }^{41}$ In this regard, PEN reactions are known to display a rich variety of spatial patterns of DNA concentration. ${ }^{34,35,43,48}$ In particular, a bistable switch in the presence of a gradient of repressor creates a non-equilibrium two- or three-band pattern at steady state. ${ }^{35}$ This last process emulates an important mechanism of pattern formation observed during early embryo development, and called positional information. ${ }^{26}$ During this mechanism, a shallow morphogen 
gradient along one axis of the embryo is translated by a gene regulatory network into a sharp pattern of protein concentration, known as the French flag. ${ }^{49}$ This protein pattern is essential and widely conserved in eukaryotic organisms for the development of the anterior-posterior axis of the embryo during cell differentiation. ${ }^{50}$

To test whether patterning by positional information was possible in reactive extracellular media, we cultured the cells in a PDMS/glass millifluidic channel in the presence of the internalization switch (Figure 5a). The channel was filled in such a way that the composition of the medium was homogeneous along the channel, except for $\mathbf{R}$ that formed a gradient from 0 to $2 \mu \mathrm{M}$, with high concentration on the right-hand-side. Figure 5b displays fluorescence profiles along the channel at an initial time for four DNA species that confirm this expectation, except for a slight inhomogeneity for species A. Indeed, the first quantitative profile was recorded $1 \mathrm{~h}$ after the assembly of the reactive medium and thus $\mathbf{A}$ can already be detected where the concentration of $\mathbf{R}$ is low because autocatalysis starts right away.

Figure 5c shows fluorescence kymographs related to the concentration of $\mathbf{A}$ in the medium (yellow) and $\mathbf{S}$ on the beads (red bead) and in the medium (red background) during this experiment. The autocatalytic production of $\mathbf{A}$ started on the left side of the channel $(x<17 \mathrm{~mm})$, where the concentration of $\mathbf{R}$ was zero, and generated a steady-state twoband pattern between $t=10 \mathrm{~h}$ and $23 \mathrm{~h}$. At $t=10 \mathrm{~h}$, when $\mathbf{A}$ reached its steady-state, it triggered the release of $\mathbf{S}$ from the beads into the medium for cellular internalization, which also formed a two-band pattern. After $23 \mathrm{~h}, \mathbf{A}$ propagated in the form of a reaction-diffusion front with a velocity of $4.3 \mu \mathrm{m} / \mathrm{min}$, while the pattern of $\mathbf{S}$ on the beads was static and its release into the medium showed minor propagation.

In the absence of cells, the spatio-temporal behaviour of the internalization switch was slightly different (Figure S17). In this case, and depending on the initial shape of the gradient, the two-band pattern of $\mathbf{A}$ either stopped or a faint front directly occurred, while the front of released $\mathbf{S}$ did not stop but propagated at constant velocity. These differences may be due to the degradation of the DNA species by the cells, an effect that should be more important 
in spatial than in temporal experiments because, for geometrical reasons, the cell volume density was 4-fold higher in the former. Indeed, the front of $\mathbf{A}$ that arises at long times in the presence of cells could be attributed to the onset of diffusion-independent autocatalysis due to a degradation of $\mathbf{R}$ by the cells. In addition, the front of $\mathbf{S}$ could be halted by cell internalization combined to the non-linear conversion of $\mathbf{A}$ into $\mathbf{S}$ (Figure S10). This could further explain why at $t=48 \mathrm{~h}$, in the presence of cells, the profile of $\mathbf{S}$ in solution is sharper than the profile of $\mathbf{A}$ (Figure $5 \mathrm{~d}$ ) - 5 and $15 \mathrm{~mm}$ width, respectively.

Despite these differences, the spatial version of the internalization switch works as designed in the presence of cells: it creates a two-band pattern of S. In addition, Figure 5e shows that, after $48 \mathrm{~h}$, the majority of cells become red on the left side of the pattern, while the inverse is true on the right side. To test that cell modification was truly controlled by positional information, we generated four different gradients of $\mathbf{R}$. Figure $5 f$ and $g$ display the images and corresponding profiles along the channel axis of the red fluorescence inside the cells for different initial conditions of $\mathbf{R}$ (Figure S18 shows the kymographs for the other species). In agreement with the temporal experiments above, in the presence of respectively high and zero concentration of $\mathbf{R}$, the cells appear dark or red along the whole channel. In contrast, the presence of a gradient of $\mathbf{R}$ made cells become red only in the zone where $\mathbf{S}$ was released. Importantly, the position of the gradient of $\mathbf{R}$ determined the width of the band of released S, and hence of that of red cells. The border between red and dark cells was, however, twice wider than that of red fluorescence in solution at final time, since cells internalize $\mathbf{S}$ over time (Figure 4). Taken together, these results demonstrate that it is possible to engineer an out-of-equilibrium reactive medium that takes as input an extracellular source of positional information that cannot be sensed by the cells, and that processes and translates it into a chemical signal that is readily internalized by living cells. 

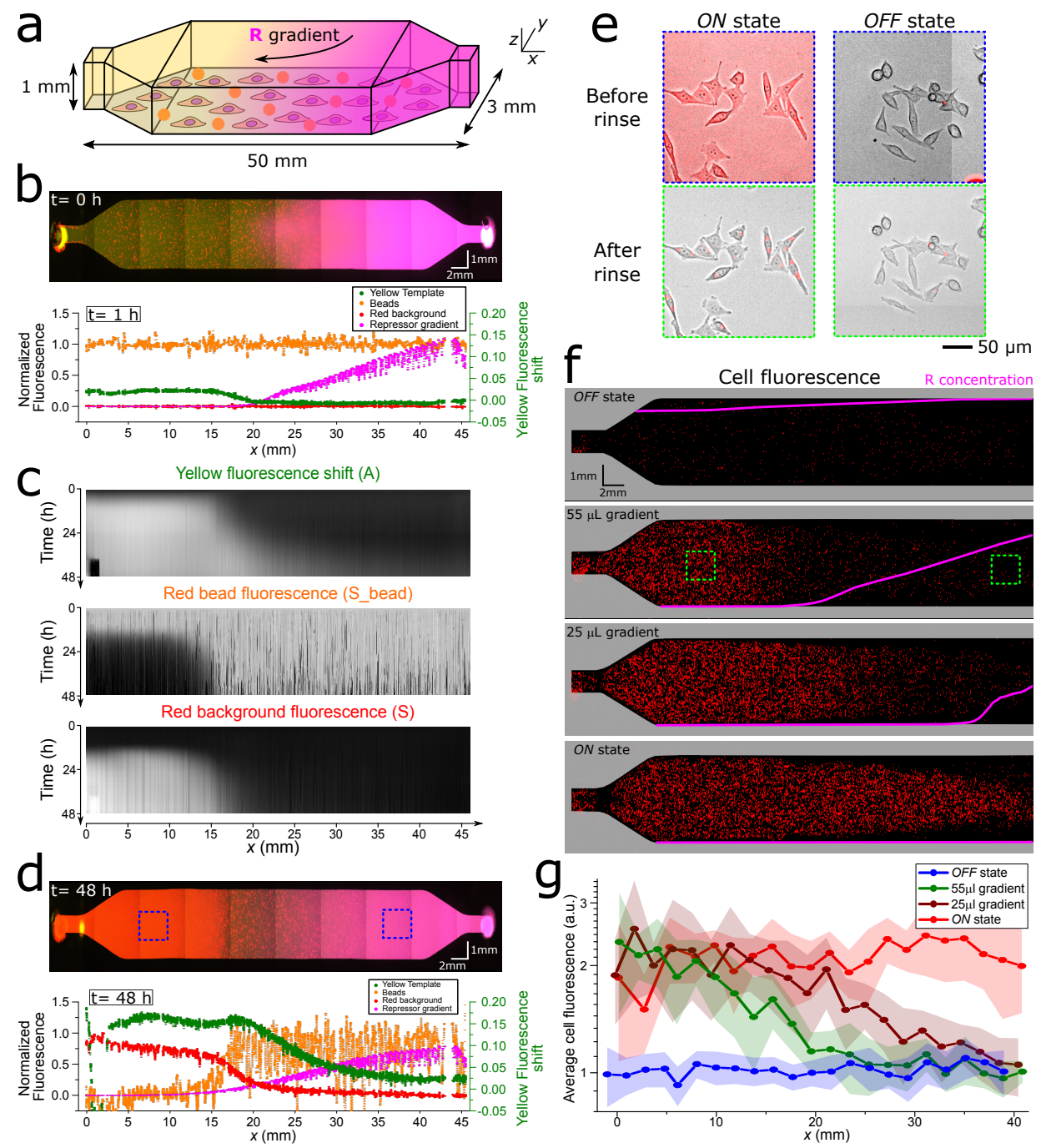

Figure 5: The reactive medium processes extracellular positional information and transfers it to the cells. a) Scheme (not to scale) of the millifluidic channel where cells, conversion beads and the medium containing the internalization switch (in yellow) are homogeneously distributed and the repressor (in magenta) forms a gradient along the $x$ axis. b) Threecolour fluorescence image of the channel at $t=0 \mathrm{~h}$ and corrected fluorescence profiles at $t=1$ h. c) Kymographs of the fluorescence profiles associated to species $\mathbf{A}$ (top), $\mathbf{S}$ on the beads (middle) and $\mathbf{S}$ in solution (bottom) d) Fluorescence image of the channel and corresponding profiles at $t=48 \mathrm{~h}$. e) Composite bright-field/red fluorescence images of the cells at $t=48 \mathrm{~h}$ in regions where the switch is ON and OFF, before and after rinsing. The corresponding regions are highlighted in panels $d$ and $f$ with dashed blue and green rectangles, respectively. f) Red fluorescence images of the rinsed cells for different initial gradients of $\mathbf{R}$ represented as magenta lines. For visualization purposes only, the images have been binarized and dilated. The grey zones correspond to the position of the channel walls before rinsing. g) Profiles of the average fluorescence per cell corresponding to the four gradients of $\mathbf{R}$ in panel f. 10 cells were measured for each point. Shades correspond to the standard deviation. To help visualization, beads profiles in panels $\mathrm{b}$ and $\mathrm{d}$ have been smoothed by an adjacent averaging of 50 data points. Panels b-e correspond to experiments with a $55 \mu \mathrm{L} \mathbf{R}$ gradient. Conditions: $[\mathrm{A}]_{0}=20 \mathrm{nM},[\mathrm{T}]_{0}=200 \mathrm{nM}$ and maximal $[\mathrm{R}]=2 \mu \mathrm{M}$. 


\section{Conclusions}

In this work, we have developed an extracellular medium that sustains out-of-equilibrium reaction networks with feedbacks. We have shown that such networks change the composition of living cells with high control both in time and space. To do so, we have found common conditions in which an extracellular DNA-enzyme program was functional in the presence of a viable culture of human cells. With these tools we have engineered a reactive extracellular medium that controls the internalization of a DNA strand inside living cells. The timing of internalization can be set either externally by adding a reagent or internally by tuning the initial composition of the medium and taking advantage of a clock reaction. In addition, we have demonstrated that reactive extracellular media may create concentration patterns that spatially control the internalization of DNA by cells, mimicking the transfer of positional information at play during early embryo development. ${ }^{29,35,51}$ Importantly, these patterns were generated autonomously by non-equilibrium chemical reactions without hydrodynamic flow, in contrast with standard methods relying on microfluidics, ${ }^{52}$ where flow introduces shear stress and washes out nutrients and signaling molecules.

Our method stands out for its simplicity. Non-equilibrium DNA programs could be run in the presence of living cells without introducing any major modification other than a variation in the composition of a classical growth medium. In particular, no chemical modification of the DNA program, no genetic modification of the cells, nor special apparatus other than standard cell culture well-plates were needed to run the autocatalytic network and the bistable switch. Only the more complex internalization program needed the addition of hydrogel beads to physically separate the cells from the output DNA strand. Interestingly, the program worked at $37^{\circ} \mathrm{C}$ and without human intervention for at least $48 \mathrm{~h}$. The presence of the enzymes that continuously synthesize fresh DNA may account for the robustness of the method, although complementary approaches based on DNA strand displacement reactions may improve the programmability of the reactive medium. ${ }^{40}$ Furthermore, the DNA programs were fast compared with cell division (3 to 7-fold), and remained active for 
two days, which could be possibly extended up to a week. ${ }^{36}$

The reactive medium shown here controlled the delivery of fluorescent DNA. However, the wide array of reactivities offered by oligonucleotides opens the way for controlling cellular behaviour, either genetically ${ }^{53}$ or via aptamers. ${ }^{10}$ In this direction, we anticipate that reactive extracellular media could be used to control cell physiology, for instance by coupling them with DNA-controlled cell adhesion, ${ }^{13}$ siRNA delivery, ${ }^{54}$ DNA-placlitaxel conjugates, ${ }^{55}$ or DNA-peptide conjugates. ${ }^{56}$ Finally, the out-of-equilibrium dynamics of the medium is advantageous to build devices responsive to a change in the cellular state. With these properties, one foresees that DNA-based reactive extracellular media could be used for real-time in vitro detection of fast evolving or long-lasting biomarkers in living cells. ${ }^{57}$ In addition, extracellular self-organizing DNA concentration patterns could provide interesting methods to engineer tissues, with differentiation induced over space and time in a controlled manner. Ultimately, reactive media could be integrated into smart bandages ${ }^{8}$ or into engineered living materials ${ }^{58}$ but also function as a detector, ${ }^{57}$ as an actuator, or both, while benefiting of the computation capabilities of DNA.

\section{Methods}

All DNA strands were designed heuristically and with the help of Nupack ${ }^{59}$ and purchased from Integrated DNA Technologies, Inc (U.S.) or Biomers (Germany). The Bst DNA polymerase large fragment and the Nb.BsmI nicking enzymes were purchased from New England Biolabs, while the Thermus thermophilus RecJ exonuclease was produced in-house as described. ${ }^{60}$

The DNA buffer was used as described previously. ${ }^{35}$ The reference cell-buffer contained DMEM supplemented with 1\% Penicillin-Streptomycin.The cell-DNA buffer contained all the components of DMEM at 2-fold dilution, 1\% Penicillin-Streptomycin and all the constituents of the DNA buffer at their standard concentration, except for $\left(\mathrm{NH}_{4}\right)_{2} \mathrm{SO}_{4}$, that 
was suppressed, and $\mathrm{NaCl}$ and dithiothreitol (DTT), whose concentrations were lowered, to reduce toxicity (see Table S1). Unless otherwise stated, all experiments were performed at $37^{\circ} \mathrm{C}$. DNA sequences and further experimental procedures are provided in the Supplementary Information.

\section{Monitoring of PEN DNA reactions}

Standard enzyme concentrations for PEN reactions were $8 \mathrm{U} / \mathrm{mL}$ polymerase, $100 \mathrm{U} / \mathrm{mL}$ nickase, $31.25 \mathrm{nM}$ exonuclease, and $0.4 \mathrm{mM}$ dNTPs (New England Biolabs). When cell culture conditions were not needed (Figure 1b), the dynamics of PEN reactions were recorded in $20 \mu \mathrm{L}$ solutions inside $150 \mu \mathrm{L}$ qPCR tubes using a Qiagen Rotor-Gene qPCR machine or a CFX96 Touch Real-Time PCR Detection System (Bio-Rad). For biological relevance, homogeneous experiments with cells were performed in well plates (see below) and their fluorescence monitored by microscopy. To calculate the fluorescence shift, the raw fluorescence intensity was normalized by an early time point $(t=5 \mathrm{~min})$, and subtracted from 1 , as done previously. ${ }^{35}$ The onset amplification time, $\tau$, was defined as the time point at which $50 \%$ of the fluorescence of the steady state of the $O N$ state was reached.

Polyacrylamide denaturing gel electrophoresis at $20 \%$ was run for $2 \mathrm{~h}$ at $200 \mathrm{~V}$ in $0.5 \mathrm{X}$ TBE buffer, stained with 1000x Sybr Gold (ThermoFisher: S11494) for 10 min, and imaged using a Gel Doc ${ }^{\text {TM }}$ EZ Gel Imager (Bio-Rad). Note that we use species $\mathbf{A}^{1}$ because upon the hydrolysis of a phosphodiester bond during the nicking event, the phosphate group remains in the 5 ' of the second trigger, since if the phosphate group remained on the 3 ' of the first trigger no autocatalytic behaviour would be attainable.

\section{Spatial experiment devices}

The $50 \mathrm{~mm}$ long, $3 \mathrm{~mm}$ wide and $1 \mathrm{~mm}$ high millifluidic channels were made out of poly(dimethylsiloxane) (PDMS, RTV 615). Firstly, a milling machine is used to create a reusable polyvinyl chloride (PVC) mold (Figure S19). PDMS (prepolymer/curing agent ratio (w/w) 
of $10: 1$ ) is subsequently poured into the mold, degassed in a vacuum chamber to remove the bubbles, and cured at $65^{\circ} \mathrm{C}$ for 1.5 hours. Once done, the PDMS layer is removed from the mold, access holes are punched on both ends of the channels, and the PDMS is gently pressed on a glass slide, both surfaces being previously plasma treated.

\section{Cell culture handling and experiments}

Human cervix epitheloid carcinoma cells (HeLa cell line) were grown at $37{ }^{\circ} \mathrm{C}$ and $5 \%$ $\mathrm{CO}_{2}$. The cells were firstly grown in two sequential steps (10\% and 5\%) of FBS (Dominique Dutscher: S1810-500) before reducing the FBS down to 2.5\%, to avoid drastic shock upon removal of FBS. The adherent culture was maintained in 2.5\% FBS cell-buffer medium until reaching 80-90\% confluence, where cells were trypsinized with trypsin-EDTA (PAN Biotech: P10-019100) and diluted into fresh 2.5\% FBS cell-buffer medium. Experiments carried out in 384 cell well plates (ThermoFisher: 142762) were seeded with 1600 cells in $50 \mu \mathrm{L}$ of medium per well. For spatial experiments, cells were seeded within the millifluidic channels using a $200 \mu \mathrm{L}$ pipette tip at $1.1 \times 10^{5}$ cells $/ \mathrm{ml}$. In both cases, the cells were allowed to adhere to the surface for $24 \mathrm{~h}$ before further experimental handling.

For cell viability experiments, the medium was removed from the well and replaced with $50 \mu \mathrm{L}$ of the buffer under test, and left for the stated number of days. For DMSO controls, $10 \mu \mathrm{L}$ of DMSO (Panreac: A3672) was directly added from stock solution. For trypan blue viability assays, $2 \mu \mathrm{L}$ of trypan blue $0.4 \%$ solution (Gibco: 15250061) was added and gently mixed. After $5 \mathrm{~min}$ in the incubator, the wells were rinsed twice with 1X PBS, always leaving some solution in the well to assure that no cells were removed during rinsing. Cells were then imaged in bright-field with a 2.5X $5324.8 \mu m^{2}$ and a 20X $644.84 \mu m^{2}$ objective.

For quantification of cells by fluorescent-activated cell sorting (FACS), the wells were gently rinsed with $50 \mu \mathrm{L} 1 \mathrm{X}$ DMEM and incubated 8 minutes with $50 \mu \mathrm{L}$ trypsin (stock solution) before inactivation with $50 \mu \mathrm{L}$ of DMEM supplemented with $10 \%$ FBS. The cell solution was mixed with $250 \mu \mathrm{L}$ FACSFlow (Fisherscientific: 12756528) and $0.5 \mu \mathrm{L}$ of pro- 
pidium iodide $\left(20 \mathrm{mM}\right.$, ThermoFisher: L7012). Heat-treated cells were left at $65{ }^{\circ} \mathrm{C}$ for 10 minutes. A Becton-Dickinson flow cytometer (FACSCalibur) equipped with a $488 \mathrm{~nm}$ argon ion laser was used to excite propidium iodide, and record the emissions in the fluorescence channel FL-2 (band pass 585/42 nm). Cells were quantified for 3 min at a flow of 60 $\mu \mathrm{L} /$ min. Fluorescent measurements were treated and analysed with a home-made Matlab (The Mathworks) routine. Note: due to the presence of a reducing agent (DTT), standard MTT viability test could not be performed.

Concerning experiments with cells in the presence of the reactive medium, for 384 well plate experiments the cell culture medium was removed and replaced with $50 \mu \mathrm{L}$ of the reactive medium. For spatial experiments, the reactive medium was injected twice gently to remove the cell culture medium without detaching the cells. The channel inlets and outlets were closed with greases, and a coverslide was pressed onto the grease for a better sealing limiting evaporation. In the case of inhomogeneous initial conditions (gradient of $\mathbf{R}$ ), two identical solutions are prepared where only one is supplemented with $\mathbf{R}$. The channel is first filled with the solution without $\mathbf{R}$ and left 5 minutes to allow the beads to sediment to the surface. Then, a precise volume of the solution containing $\mathbf{R}$ is injected. A gentle back and forth pipetting is performed 5 times to generate a gradient of $\mathbf{R}$ along the channel, while all other components remain homogeneously distributed. Figure S19 shows, with the use of methylene blue dye, the visual appearance of the gradients obtained using this setup. For visualization of the $\mathbf{R}$ gradients, $\mathbf{R}^{1}$ was used at $10 \%$ of the desired final $\mathbf{R}$ concentration.

\section{Particle loading}

Conversion beads were constituted of porous streptavidin-conjugated sepharose hydrogel with $34 \mu \mathrm{m}$ average particle size (GE healthcare: GE17-5113-01) functionalized with biotinylated DNA constructs. Firstly, we annealed 290 pmoles of double-biotinylated $\mathbf{C}_{\mathbf{1}}$ with 247 pmoles of $\mathbf{S}$ in a $115.7 \mu \mathrm{L} 5 \mathrm{mM} \mathrm{MgSO}$ solution with a temperature ramp of $1{ }^{\circ} \mathrm{C}$ every $10 \mathrm{~s}$, from $90{ }^{\circ} \mathrm{C}$ to $20{ }^{\circ} \mathrm{C}$. Secondly, we rinsed twice $5 \mu \mathrm{L}$ of Sepharose solution $(\sim 10000$ 
beads $/ \mu \mathrm{L}$ ) with washing buffer (10 mM Tris-HCl, $\mathrm{pH}$ 7.5, $2 \mathrm{M} \mathrm{NaCl}, 1 \mathrm{mM}$ EDTA, 0.2\% Tween 20), followed by a third wash with deionized water and decantation. The DNA annealed solution was mixed with the rinsed beads and immediately agitated for 10 seconds, to further incubate it at $40{ }^{\circ} \mathrm{C}$ for $30 \mathrm{~min}$, with agitation to avoid particle sedimentation. Finally, the functionalized beads were rinsed three times with a $5 \mathrm{mM} \mathrm{MgSO}_{4}$ solution to remove unbound DNA, and the final volume was adjusted to $100 \mu \mathrm{L}$. Functionalized beads were used at $0.62 \%$ and $1.67 \%$ for the 384 well plate and the spatial experiments respectively, which accounted for low surface coverage (Figure S9).

\section{Microscopy}

PEN DNA reactions (with and without cells) were monitored using a Zeiss Axio Observer Z1 fully automated epifluorescence microscope equipped with a ZEISS Colibri 7 LED light, YFP and RFP filter sets, and a Hamamatsu ORCA-Flash4.0V3 inside a Zeiss incubation system to regulate temperature at $37^{\circ} \mathrm{C}$, in the presence of high humidity and at $5 \% \mathrm{CO}_{2}$. Note: we observed up to a $75 \%$ reduction in $\tau$ for 384 well plates (Figure 2a) than that for $\mathrm{qPCR}$ machines (Figure 1b), which we mainly attribute to a difference in the materials of the two containers used (polystyrene wells and polypropylene tubes respectively) and to a lower robustness of the microscope to maintain a constant temperature compared to a thermocycler. Multi-color fluorescence and bright-field images were recorded every $10 \mathrm{~min}$ (Figure 2), 35 min (Figure 4) or $1 \mathrm{~h}$ (Figure 3 ) with a 2.5X objective, and every $1 \mathrm{~h}$ with a 72-by-1 image array using a 10X $648.1 \mu \mathrm{m}^{2}$ objective for Figure 5. For spatial experiments, prior and following temporal dynamics, the entire millifluidic channel was imaged with a 2.5X objective.

To detect cellular internalization, cells in 384 well plates were rinsed twice with $60 \mu \mathrm{L}$ of DMEM (with a $5 \mathrm{~min}$ incubation at $37^{\circ} \mathrm{C}$ between rinses) and the entire well was imaged with a 4-by-4 image array using a 20X objective. For cells in the millifluidic channel, the PDMS device was removed and each channel was rinsed twice with $1 \mathrm{~mL}$ of DMEM, to later 
be imaged with a 40-by-4 image array using a 10X objective (Figure 5f), and a 72-by-1 image array using a 20X objective (Figure $5 \mathrm{~g}$ ).

\section{Image and data treatment}

The raw microscopy images were treated with ImageJ / Fiji (NIH) and Matlab. To follow the dynamics of the PEN reactions, time-lapse images were imported into a stack for each well. Three threshold values were defined to select the template fluorescence (yellow channel), the background fluorescence and the bead fluorescence (red channel). In the case of the beads, pixels were only selected if they stayed within the selection criteria for more than half the duration of the experiment, to avoid disturbances caused by the movement of the beads. Each thresholded image was averaged along the $y$ axis to create an intensity profile at each time point. These profiles were stacked over time into a kymograph, which was then normalized by the profile of an initial time point to correct from inhomogeneous illumination. The kymographs were then averaged over space to obtain the profiles of intensity versus time. To correct from time-dependent artefacts introduced by the microscope when performing experiments in 384 well plates, the profiles of each well were normalized with a negative control (absence of enzymes, $n=2$ ). In spatial experiments, the inhomogeneous illumination in the repressor $(\mathbf{R})$ gradients was corrected by dividing each frame of the channel by a frame in the absence of $\mathbf{R}$ (left most side of the channel). Furthermore, to adjust all the $x$ positions of the kymographs to the same spatial position, the kymographs corresponding to the template fluorescence, the background fluorescence and the $\mathbf{R}$ gradient were re-plotted with only the same $x$ position as the kymograph of the beads. Fluorescence shifts were calculated as described above.

For the characterization of cellular fluorescence of experiments performed in 384 well plates, and prior to combining images into the 4-by-4 image array, the background of red fluorescence images was subtracted using ImageJ 'subtract background' routine with a 2000 pixel rolling ball radius and sliding paraboloid parameters. Subsequently, the mean back- 
ground fluorescence was removed from the image to have a homogenous background within the image array. The contour of each cell was manually selected in the bright-field image and used to extract the average red fluorescence of each cell. Selection of cells was restricted to the middle of the wells to avoid optical artefacts. For spatial experiments, due to higher efficacy of the rinsing, the average red fluorescence of each cell could be directly quantified from the image.

\section{Supporting information}

The Supporting Information contains further experimental methods, a discussion of the buffer screening process and details on the composition, DNA sequences, 19 supporting figures and 1 supporting video.

\section{Acknowledgements}

We thank Stéphanie Bonneau and Ramón Eritja for supplying the cells, Clara BerenguerEscuder for advice with cell culture, Nelly Henry for help with the FACS, and Matthieu Morel, Yannick Rondelez and Guillaume Ginés for insightful discussions. We also thank the financial support from the European Research Council (ERC) under the European's Union Horizon 2020 program (grant no. 770940, A.E.-T.), by the Ville de Paris Emergences program (Morphoart, A.E.-T.), by a Marie Sklodowska-Curie fellowship (grant no. 795580, M.vdH.) from the European Union's Horizon 2020 program, and by a PRESTIGE grant (grant no. 609102, M.vdH.) from the European Union's Seventh Framework Programme.

\section{Author contributions}

All authors designed research, discussed the results and wrote the paper. M.vdH. designed and performed the experiments and analysed the data. 


\section{Associated content}

A preliminary version of this work has been submitted to bioRxiv. ${ }^{61}$

\section{TOC figure}
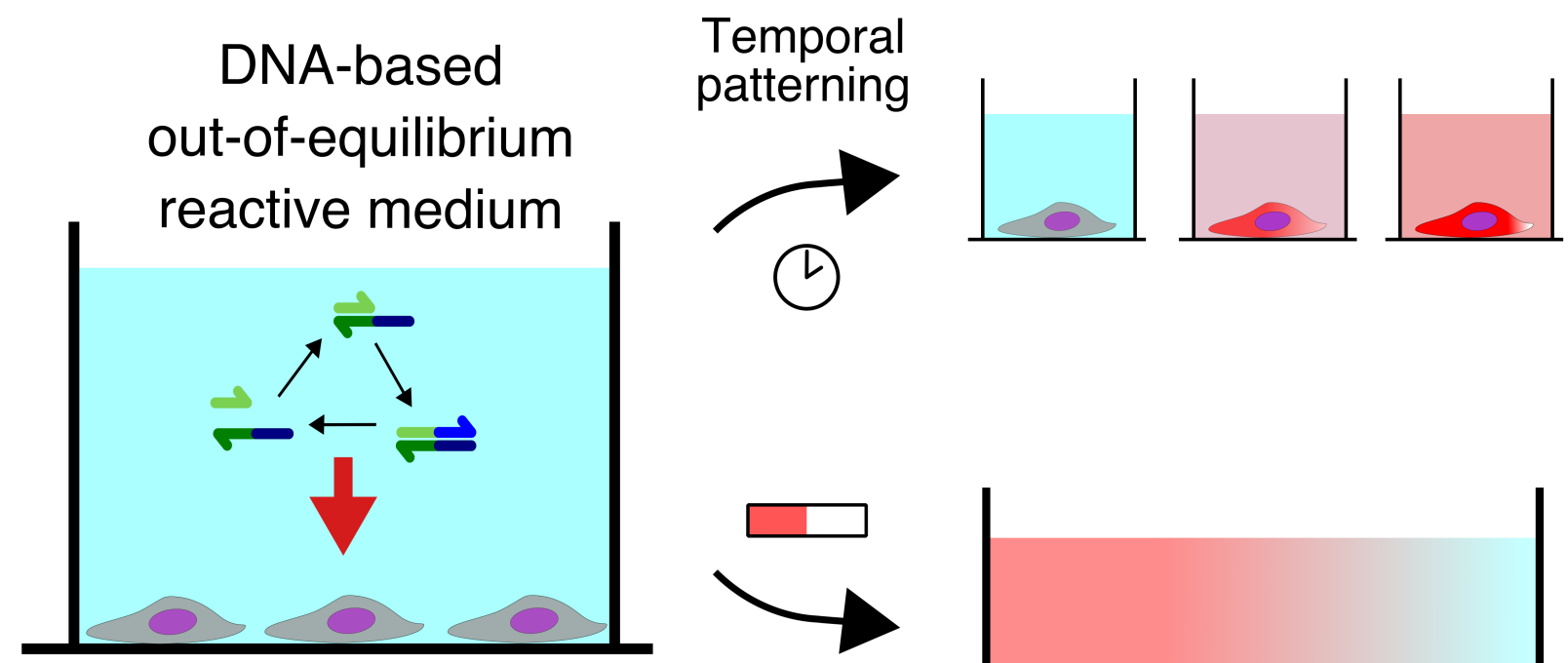

Cell culture

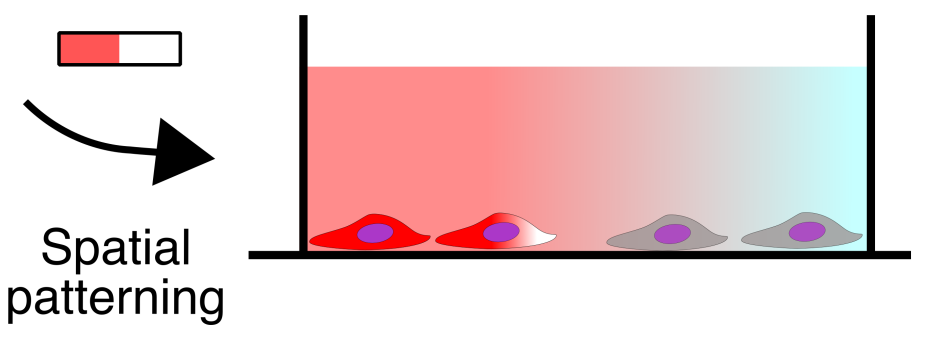

Figure 6: For Table of Contents Only 


\section{References}

1. Cameron, D. E.; Bashor, C. J.; Collins, J. J. A Brief History of Synthetic Biology. Nat Rev Micro 2014, 12, 381-390.

2. Kelly, C. L.; Liu, Z.; Yoshihara, A.; Jenkinson, S. F.; Wormald, M. R.; Otero, J.; EstÃ@evez, A.; Kato, A.; Marqvorsen, M. H. S.; Fleet, G. W. J.; Estévez, R. J.; Izumori, K.; Heap, J. T. Synthetic Chemical Inducers and Genetic Decoupling Enable Orthogonal Control of the rhaBAD Promoter. ACS Synthetic Biology 2016, 5, 1136-1145.

3. Wan, X.; Marsafari, M.; Xu, P. Engineering Metabolite-Responsive Transcriptional Factors to Sense Small Molecules in Eukaryotes: Current State and Perspectives. Microbial Cell Factories 2019, 18, 61.

4. Shimizu-Sato, S.; Huq, E.; Tepperman, J. M.; Quail, P. H. A Light-Switchable Gene Promoter System. Nature Biotechnology 2002, 20, 1041-1044.

5. Toda, S.; Blauch, L. R.; Tang, S. K. Y.; Morsut, L.; Lim, W. A. Programming SelfOrganizing Multicellular Structures with Synthetic Cell-Cell Signaling. Science 2018, 361, eaat0271.

6. Greber, D.; Fussenegger, M. An Engineered Mammalian Band-Pass Network. Nucleic Acids Research 2010, 38, e174-e174.

7. Johnson, M. B.; March, A. R.; Morsut, L. Engineering Multicellular Systems: Using Synthetic Biology to Control Tissue Self-Organization. Current opinion in biomedical engineering 2017, 4, 163-173.

8. Derakhshandeh, H.; Kashaf, S. S.; Aghabaglou, F.; Ghanavati, I. O.; Tamayol, A. Smart Bandages: The Future of Wound Care. Trends in Biotechnology 2018, 36, 1259-1274.

9. Acar, M.; Mettetal, J. T.; Van Oudenaarden, A. Stochastic Switching as a Survival Strategy in Fluctuating Environments. Nature Genetics 2008, 40, 471-475. 
10. Chen, Y. J.; Groves, B.; Muscat, R. A.; Seelig, G. DNA Nanotechnology from the Test Tube to the Cell. Nature Nanotechnology 2015, 10, 748-760.

11. Douglas, S. M.; Bachelet, I.; Church, G. M. A Logic-Gated Nanorobot for Targeted Transport of Molecular Payloads. Science 2012, 335, 831-834.

12. Li, S.; Jiang, Q.; Liu, S.; Zhang, Y.; Tian, Y.; Song, C.; Wang, J.; Zou, Y.; Anderson, G. J.; Han, J. Y.; Chang, Y.; Liu, Y.; Zhang, C.; Chen, L.; Zhou, G.; Nie, G.; Yan, H.; Ding, B.; Zhao, Y. A DNA Nanorobot Functions as a Cancer Therapeutic in Response to a Molecular Trigger in Vivo. Nature Biotechnology 2018, 36, 258-264.

13. Freeman, R.; Stephanopoulos, N.; Álvarez, Z.; Lewis, J. A.; Sur, S.; Serrano, C. M.; Boekhoven, J.; Lee, S. S.; Stupp, S. I. Instructing Cells with Programmable Peptide DNA Hybrids. Nature Communications 2017, 8, 15982.

14. Bhatia, D.; Arumugam, S.; Nasilowski, M.; Joshi, H.; Wunder, C.; Chambon, V.; Prakash, V.; Grazon, C.; Nadal, B.; Maiti, P. K.; Johannes, L.; Dubertret, B.; Krishnan, Y. Quantum Dot-Loaded Monofunctionalized DNA Icosahedra for Single-Particle Tracking of Endocytic Pathways. Nature Nanotechnology 2016, 11, 1112-1119.

15. Rudchenko, M.; Taylor, S.; Pallavi, P.; Dechkovskaia, A.; Khan, S.; Butler, V. P.; Rudchenko, S.; Stojanovic, M. N. Autonomous Molecular Cascades for Evaluation of Cell Surfaces. Nature Nanotechnology 2013, 8, 580-586.

16. You, M.; Zhu, G.; Chen, T.; Donovan, M. J.; Tan, W. Programmable and Multiparameter DNA-Based Logic Platform for Cancer Recognition and Targeted Therapy. Journal of the American Chemical Society 2015, 137, 667-674.

17. Song, T.; Shah, S.; Bui, H.; Garg, S.; Eshra, A.; Fu, D.; Yang, M.; Mokhtar, R.; Reif, J. Programming DNA-Based Biomolecular Reaction Networks on Cancer Cell Membranes. Journal of the American Chemical Society 2019, 141, 16539-16543. 
18. Rinaudo, K.; Bleris, L.; Maddamsetti, R.; Subramanian, S.; Weiss, R.; Benenson, Y. A Universal RNAi-Based Logic Evaluator that Operates in Mammalian Cells. Nature Biotechnology 2007, 25, 795-801.

19. Chatterjee, G.; Chen, Y. J.; Seelig, G. Nucleic Acid Strand Displacement with Synthetic mRNA Inputs in Living Mammalian Cells. ACS Synthetic Biology 2018, 7, 2737-2741.

20. Lentini, R.; Santero, S. P.; Chizzolini, F.; Cecchi, D.; Fontana, J.; Marchioretto, M.; Del Bianco, C.; Terrell, J. L.; Spencer, A. C.; Martini, L.; Forlin, M.; Assfalg, M.; Serra, M. D.; Bentley, W. E.; Mansy, S. S. Integrating Artificial with Natural Cells to Translate Chemical Messages That Direct E. Coli Behaviour. Nature Communications 2014, 5, 4012 .

21. Schwarz-Schilling, M.; Aufinger, L.; Mückl, A.; Simmel, F. C. Chemical Communication Between Bacteria and Cell-Free Gene Expression Systems within Linear Chains of Emulsion Droplets. Integrative Biology (United Kingdom) 2016, 8, 564-570.

22. Lentini, R.; Martín, N. Y.; Forlin, M.; Belmonte, L.; Fontana, J.; Cornella, M.; Martini, L.; Tamburini, S.; Bentley, W. E.; Jousson, O.; Mansy, S. S. Two-Way Chemical Communication between Artificial and Natural Cells. ACS Central Science 2017, 3, $117-123$.

23. Toparlak, O. D.; Zasso, J.; Bridi, S.; Serra, M. D.; Macchi, P.; Conti, L.; Baudet, M.-L.; Mansy, S. S. Artificial Cells Drive Neural Differentiation. Science Advances 2020, 6.

24. Niederholtmeyer, H.; Stepanova, V.; Maerkl, S. J. Implementation of Cell-Free Biological Networks at Steady State. Proceedings of the National Academy of Sciences 2013,

25. Karzbrun, E.; Tayar, A. M.; Noireaux, V.; Bar-Ziv, R. H. Programmable on-Chip DNA Compartments as Artificial Cells. Science 2014, 345, 829-832. 
26. Briscoe, J.; Small, S. Morphogen Rules: Design Principles of Gradient-Mediated Embryo Patterning. Development 2015, 142, 3996-4009.

27. Montagne, K.; Plasson, R.; Sakai, Y.; Fujii, T.; Rondelez, Y. Programming an in Vitro DNA Oscillator Using a Molecular Networking Strategy. Mol Syst Biol 2011, 7, 466, 10.1038/msb.2010.120.

28. Van Der Hofstadt, M.; Gines, G.; Galas, J.-C.; Estevez-Torres, A. Programming SpatioTemporal Patterns with DNA-Based Circuits. In DNA- and RNA-Based Computing Systems; Evgeny, K., Ed.; Wiley-VCH, London, 2021.

29. Urtel, G.; Van Der Hofstadt, M.; Galas, J. C.; Estevez-Torres, A. Rexpar: An Isothermal Amplification Scheme That is Robust to Autocatalytic Parasites. Biochemistry 2019, $58,2675-2681$.

30. Fujii, T.; Rondelez, Y. Predator-Prey Molecular Ecosystems. ACS Nano 2013, 7, 27-34.

31. Padirac, A.; Fujii, T.; Rondelez, Y. Bottom-Up Construction of in Vitro Switchable Memories. Proceedings of the National Academy of Sciences 2012, 10.1073/pnas.1212069109, 10.1073/pnas.1212069109.

32. Montagne, K.; Gines, G.; Fujii, T.; Rondelez, Y. Boosting Functionality of Synthetic DNA Circuits with Tailored Deactivation. Nature Communications 2016, 7, 13474.

33. Meijer, L. H. H.; Joesaar, A.; Steur, E.; Engelen, W.; van Santen, R. A.; Merkx, M.; de Greef, T. F. A. Hierarchical Control of Enzymatic Actuators Using DNA-Based Switchable Memories. Nature Communications 2017, 8, 1117.

34. Padirac, A.; Fujii, T.; Estevez-Torres, A.; Rondelez, Y. Spatial Waves in Synthetic Biochemical Networks. Journal of the American Chemical Society 2013, 135, 14586-14592, doi: 10.1021/ja403584p. 
35. Zadorin, A. S.; Rondelez, Y.; Gines, G.; Dilhas, V.; Urtel, G.; Zambrano, A.; Galas, J. C.; Estevez-Torres, A. Synthesis and Materialization of a Reaction-Diffusion French Flag Pattern. Nature Chemistry 2017, 9, 990-996.

36. Urtel, G.; Estevez-Torres, A.; Galas, J.-C. DNA-Based Long-Lived Reaction-Diffusion Patterning in a Host Hydrogel. Soft Matter 2019, 15, 9343-9351.

37. Baccouche, A.; Montagne, K.; Padirac, A.; Fujii, T.; Rondelez, Y. Dynamic DNAToolbox Reaction Circuits: A Walkthrough. Methods 2014, 67, 234-249.

38. Padirac, A.; Fujii, T.; Rondelez, Y. Quencher-Free Multiplexed Monitoring of DNA Reaction Circuits. Nucleic Acids Research 2012, 40, e118-e118.

39. Xiang, X.-Y.; Yang, X.-C.; Su, J.; Kang, J.-S.; Wu, Y.; Xue, Y.-N.; Dong, Y.-T.; Sun, L.K. Inhibition of Autophagic Flux by ROS Promotes Apoptosis during DTT-Induced ER/Oxidative Stress in HeLa Cells. Oncology Reports 2016, 35, 3471-3479.

40. Fern, J.; Schulman, R. Design and Characterization of DNA Strand-Displacement Circuits in Serum-Supplemented Cell Medium. ACS Synthetic Biology 2017, 6, 1774-1783.

41. Epstein, I.; Pojman, J. A. An Introduction to Nonlinear Chemical Reactions; Oxford University Press: New York, 1998.

42. Zhao, Q.; Matson, S.; Herrera, C. J.; Fisher, E.; Yu, H.; Krieg, A. M. Comparison of Cellular Binding and Uptake of Antisense Phosphodiester, Phosphorothioate, and Mixed Phosphorothioate and Methylphosphonate Oligonucleotides. Antisense Research and Development 1993, 3, 53-66.

43. Gines, G.; Zadorin, A. S.; Galas, J. C.; Fujii, T.; Estevez-Torres, A.; Rondelez, Y. Microscopic Agents Programmed by DNA Circuits. Nature Nanotechnology 2017, 12, $351-359$. 
44. Zhang, D. Y.; Seelig, G. Dynamic DNA Nanotechnology Using Strand-Displacement Reactions. Nat Chem 2011, 3, 103-113, 10.1038/nchem.957.

45. Nödling, A. R.; Mills, E. M.; Li, X.; Cardella, D.; Sayers, E. J.; Wu, S.-H.; Jones, A. T.; Luk, L. Y. P.; Tsai, Y.-H. Cyanine Dye Mediated Mitochondrial Targeting Enhances the Anti-Cancer Activity of Small-Molecule Cargoes. Chemical Communications 2020,

46. Juliano, R. L. The Delivery of Therapeutic Oligonucleotides. Nucleic acids research 2016, 44, 6518-6548.

47. Crooke, S. T.; Wang, S.; Vickers, T. A.; Shen, W.; Liang, X.-h. Cellular Uptake and Trafficking of Antisense Oligonucleotides. Nature Biotechnology 2017, 35, 230-237.

48. Zadorin, A. S.; Rondelez, Y.; Galas, J.-C.; Estevez-Torres, A. Synthesis of Programmable Reaction-Diffusion Fronts Using DNA Catalyzers. Phys. Rev. Lett. 2015, 114, 068301.

49. Wolpert, L. Positional Information and the Spatial Pattern of Cellular Differentiation. J. theor. Biol. 1969, 25, 1-47.

50. Akam, M. Hox and HOM: Homologous Gene Clusters in Insects and Vertebrates. Cell 1989, 57, $347-349$.

51. Senoussi, A.; Vyborna, Y.; Berthoumieux, H.; Galas, J.-C.; Estevez-Torres, A. Learning from Embryo Development to Engineer Self-Organizing Materials. In Out-of-Equilibrium (Supra)molecular Systems and Materials; Giuseppone, N., Walther, A., Eds.; WileyVCH, London, 2021.

52. Kim, S.; Kim, H. J.; Jeon, N. L. Biological Applications of Microfluidic Gradient Devices. integrative Biology 2010, 2, 584-603.

53. Lundin, K. E.; Gissberg, O.; Smith, C. E. Oligonucleotide Therapies: The Past and the Present. Human Gene therapy 2015, 26, 475-485. 
54. Ren, K.; Liu, Y.; Wu, J.; Zhang, Y.; Zhu, J.; Yang, M.; Ju, H. A DNA Dual Lock-andKey Strategy for Cell-Subtype-Specific siRNA Delivery. Nature Communications 2016, 7, 13580.

55. Li, F.; Lu, J.; Liu, J.; Liang, C.; Wang, M.; Wang, L.; Li, D.; Yao, H.; Zhang, Q.; Wen, J.; Zhang, Z.-K.; Li, J.; Lv, Q.; He, X.; Guo, B.; Guan, D.; Yu, Y.; Dang, L.; Wu, X.; Li, Y. et al. A Water-Soluble Nucleolin Aptamer-Paclitaxel Conjugate for Tumor-Specific Targeting in Ovarian Cancer. Nature Communications 2017, 8, 1390.

56. Ämmälä, C.; Drury, W. J.; Knerr, L.; Ahlstedt, I.; Stillemark-Billton, P.; WennbergHuldt, C.; Andersson, E. M.; Valeur, E.; Jansson-LÃ $q$ fmark, R.; JanzÃ@en, D.; SundstrÃ $₫ \mathrm{~m}$, L.; Meuller, J.; Claesson, J.; Andersson, P.; Johansson, C.; Lee, R. G.; Prakash, T. P.; Seth, P. P.; Monia, B. P.; Andersson, S. Targeted Delivery of Antisense Oligonucleotides to Pancreatic $\beta$-Cells. Science Advances 2018, 4, eaat3386.

57. Gines, G.; Menezes, R.; Nara, K.; Kirstetter, A.-S.; Taly, V.; Rondelez, Y. Isothermal Digital Detection of Micrornas Using Background-Free Molecular Circuit. Science Advances 2020,6 .

58. Guo, S.; Dubuc, E.; Rave, Y.; Verhagen, M.; Twisk, S. A. E.; van der Hek, T.; Oerlemans, G. J. M.; van den Oetelaar, M. C. M.; van Hazendonk, L. S.; BrÃCEls, M.; Eijkens, B. V.; Joostens, P. L.; Keij, S. R.; Xing, W.; Nijs, M.; Stalpers, J.; Sharma, M.; Gerth, M.; Boonen, R. J. E. A.; Verduin, K. et al. Engineered Living Materials Based on Adhesin-Mediated Trapping of Programmable Cells. ACS Synthetic Biology 2020, 9, $475-485$.

59. Zadeh, J. N.; Steenberg, C. D.; Bois, J. S.; Wolfe, B. R.; Pierce, M. B.; Khan, A. R.; Dirks, R. M.; Pierce, N. A. Nupack: Analysis and Design of Nucleic Acid Systems. Journal of Computational Chemistry 2011, 32, 170-173.

60. Wakamatsu, T.; Kitamura, Y.; Kotera, Y.; Nakagawa, N.; Kuramitsu, S.; Masui, R. 
Structure of RecJ Exonuclease Defines Its Specificity for Single-Stranded DNA. J Biol Chem 2010, 285, 9762-9.

61. Van Der Hofstadt, M.; Galas, J.-C.; Estevez-Torres, A. Engineering an Active Extracellular Medium with DNA Programs. bioRxiv 2020, https://doi.org/10.1101/2020.05.14.096065 (accessed Dec. 10, 2020). 


\section{Supplementary information for:}

\section{Spatio-Temporal Patterning of Living Cells with Extracellular DNA Programs}

Marc Van Der Hofstadt, ${ }^{*}$ Jean-Christophe Galas, ${ }^{*}$ and André Estevez-Torres*

Sorbonne Université, CNRS, Institut de Biologie Paris-Seine (IBPS), Laboratoire Jean Perrin (LJP), F-75005, Paris, France

E-mail: marcvdhs@gmail.com; jean-christophe.galas@upmc.fr; andre.estevez-torres@upmc.fr 


\section{Contents}

1 Methods $\quad 3$

2 Buffer screening $\quad 5$

3 Tables S1 to S2 11

4 Figures S5 to S14 14

5 Video S1 $\quad 29$

$\begin{array}{lr}\text { References } & 30\end{array}$ 


\section{Methods}

\subsection{Determining the cytotoxicity of the PEN DNA toolbox com- ponents}

Each component used in standard PEN reactions ${ }^{1}$ was individually tested to know its relative cytotoxicity on living HeLa cells. 3200 cells were cultured in 96 cell well plates with $2.5 \%$ FBS for $24 \mathrm{~h}$, allowing cells sufficient time to adhere to the surface. The medium was then replaced with $100 \mu \mathrm{L}$ of medium containing 1\% Penicillin-Streptomycin, Dulbecco's modified Eagle's medium (DMEM) and the compound of interest at the stated concentration. Viability was determined by the visual appearance of cells after the specified incubation times. Bright-field images $\left(581 \times 486 \mu m^{2}\right)$ were taken with an Olympus CK2 Inverted Microscope, 10X objective and a Point Grey BFS-U3-51S5M-C camera. Images represent the general appearance of cells at each tested condition (per duplicate).

\subsection{Determining reaction rates of individual enzymes}

The reaction rates for each enzyme were measured in different buffers and temperatures by following the fluorescence signal over time of a reference substrate in the presence of the enzyme. For the BsmI nicking enzyme, the reference substrate was a DNA molecular beacon whose stem carried the nicking enzyme recognition site $\left(\mathrm{ref}_{1}\right)$. The nicking event caused the release of a short fluorescent oligonucleotide, and hence an increase in the fluorescence along the reaction. For the exonuclease, the reference substrate was a 16-mer oligonucleotide $\left(\mathrm{ref}_{2}\right)$ at $1 \mu \mathrm{M}$ in the presence of a fluorescent DNA intercalator (EvaGreen, Biotium). The degradation of this oligonucleotide by the exonuclease causes a reduction in fluorescence over time.

The fluorescence signals were measured from $20 \mu \mathrm{L}$ solutions using a Bio-rad CFX qPCR: it increased (or decreased) linearly until reaching a plateau. Raw fluorescence signals were normalized between 0 and 1 and converted to DNA concentrations by multiplying them by 
the substrate concentration. These treated data were fitted by a linear function and the slope provided the rates displayed in Figure S6.

\subsection{Determining trigger concentrations at steady states.}

The steady-state trigger concentration $\left([\mathrm{A}]_{s s}\right)$ was measured at $37{ }^{\circ} \mathrm{C}$ in the Rotor-Gene ${ }_{\mathrm{qPCR}}$ machine for both the $\mathbf{A}$ and the $\mathbf{A}_{1}$ amplification sequences as previously described. ${ }^{2}$ Firstly, $20 \mu \mathrm{L}$ of exponential amplification was left until it reached steady state (900 and $1200 \mathrm{~min}$ in this case) with $50 \mathrm{nM}$ of template and $0.5 \mathrm{nM}$ of initial trigger concentrations. Secondly, an extract from this solution (1\% and 5\% in this case) was introduced into a fresh exponential reaction. Simultaneously, a calibration curve was done with a range of the initial trigger concentration, to extract the autocatalytic rate from the amplification onset times. Using the autocatalytic rate, the predicted initial trigger concentration of the condition under test can be extracted from their amplification onset times. The initial trigger concentration is then multiplied by 100 or 20 (for $1 \%$ and $5 \%$ extracts, respectively) to determine the trigger concentrations at steady states in Figure S5. 


\section{Buffer screening}

Both living cells and the PEN DNA toolbox rely on biochemical reactions to sustain, but each has its own buffer composition. Living cells require a rich nutritious medium, while that of the PEN DNA toolbox is relatively simple and admits variations. ${ }^{3}$ Due to a higher flexibility and robustness of PEN reactions, ${ }^{4}$ we decided in prioritizing cellular viability over PEN reactions' efficiency when attaining a buffer compatible to cell growth and PEN reactions.

Firstly, we screened the standard PEN DNA toolbox for cytotoxic components, with interest in obtaining a biocompatible enzyme-based DNA program without significant cell death for at least 3 days. To do so, we broke down the DNA buffer into its components to assess each component individually, in addition of testing the cytotoxicity of DNA and enzymes (Figure S1 and Figure S2). After 22 h, we already observed a high mortality of HeLa cells in the presence of the PP buffer (a home made buffer). The PP buffer cannot be entirely removed, since it contains the essential compounds for the PEN reactions; the energy source (dNTPs), and $\mathrm{MgSO}_{4}$, which is essential for DNA dynamics. ${ }^{5}$ For this reason, the PP buffer was further broken down, and each constituent was tested individually at their working concentration (Figure S1 middle panel). While the essential components for the PEN reactions didn't present cell toxicity (dNTPS and $\mathrm{MgSO}_{4}$ ), after $47 \mathrm{~h}$ the cytotoxic components of the PP buffer were evident. The addition of sodium chloride, or of Thermopol buffer (home made variation to the commercial one) presented significant cell death. Since the cell culture medium (DMEM) contains $120 \mathrm{mM}$ of sodium chloride, we deducted that the further addition of $50 \mathrm{mM}$ could increase drastically osmolarity, and hence cause cellular death. As DMEM contains more than double what is needed for the PEN reactions, we decided that the further addition of sodium chloride was not needed. For the other cytotoxic component of the PP buffer, the Thermopol buffer, we repeated the procedure and broke it down into its constituents, and further tested them individually (Figure S1 bottom panel). Here, we found that ammonium sulphate was the cytotoxic component, hence inferring that 
removing the sodium chloride and the ammonium sulphate would make a biocompatible PP buffer.
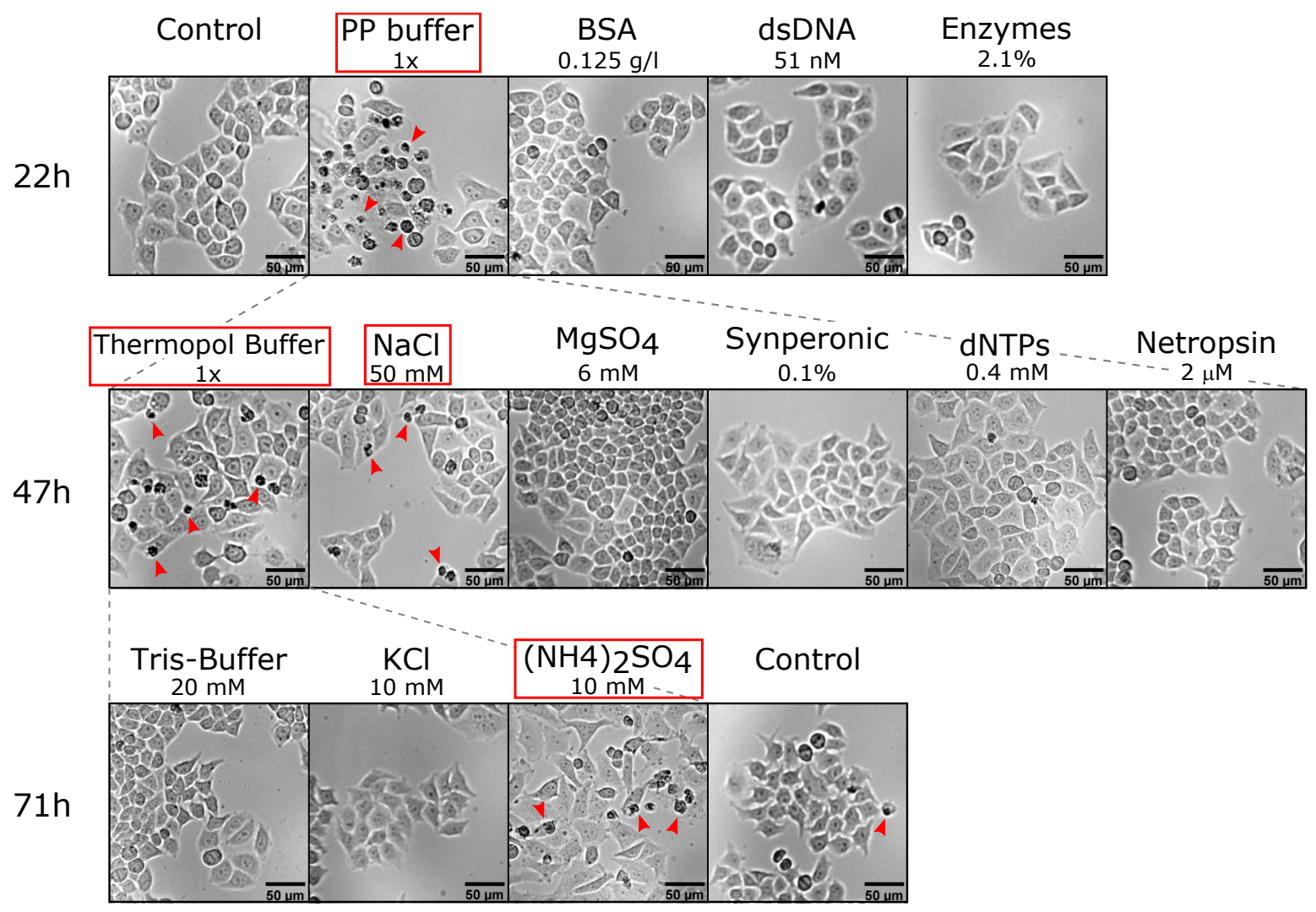

Figure S1: Screening the cytotoxic components of the PEN DNA toolbox. Bright-field images of HeLa cells after their incubation in the presence of the different components used for PEN reactions, at their respective working concentrations. The top panel shows the major components of the PEN DNA toolbox after $22 \mathrm{~h}$ of incubation, the middle panel the components forming the PP buffer after $47 \mathrm{~h}$ of incubation, and the lower panel shows the components of the Thermopol buffer after $71 \mathrm{~h}$ of incubation. Control shows cells incubated only in the presence of $1 \%$ Penicillin-Streptomycin and DMEM. BSA stands for Bovine Serum Albumin (New England biolabs: B9000S), and dsDNA indicates 50nM of strand $\mathbf{T}_{1}$ and $1 \mathrm{nM}$ of strand $\mathbf{A}_{1}$. Red arrowheads are placed to help the visualization of dead cells, which appear as black debris.

While the PP buffer resulted in being cytotoxic for cells, dithiothreitol (DTT) affected cellular integrity by causing the partial detachment of the cells from the surface (Figure S2). In particular, DTT presented a faster dynamics, observing detachment after only $4 \mathrm{~h}$ of incubation, but also presenting a recovery stage, where cells re-attached onto the surface. 
Concentrations used for standard PEN reactions $(3 \mathrm{mM})$ resulted in very high levels of cellular detachment, and recovery periods longer than 2 days. Upon the reduction of DTT by one order of magnitude, recovery periods were shorter than 1 day, and the cells affected by detachment were low. Since cellular detachment affects cellular growth, ${ }^{6}$ we included DTT as a cytotoxic components to remove (or reduce in concentration) from the DNA buffer.

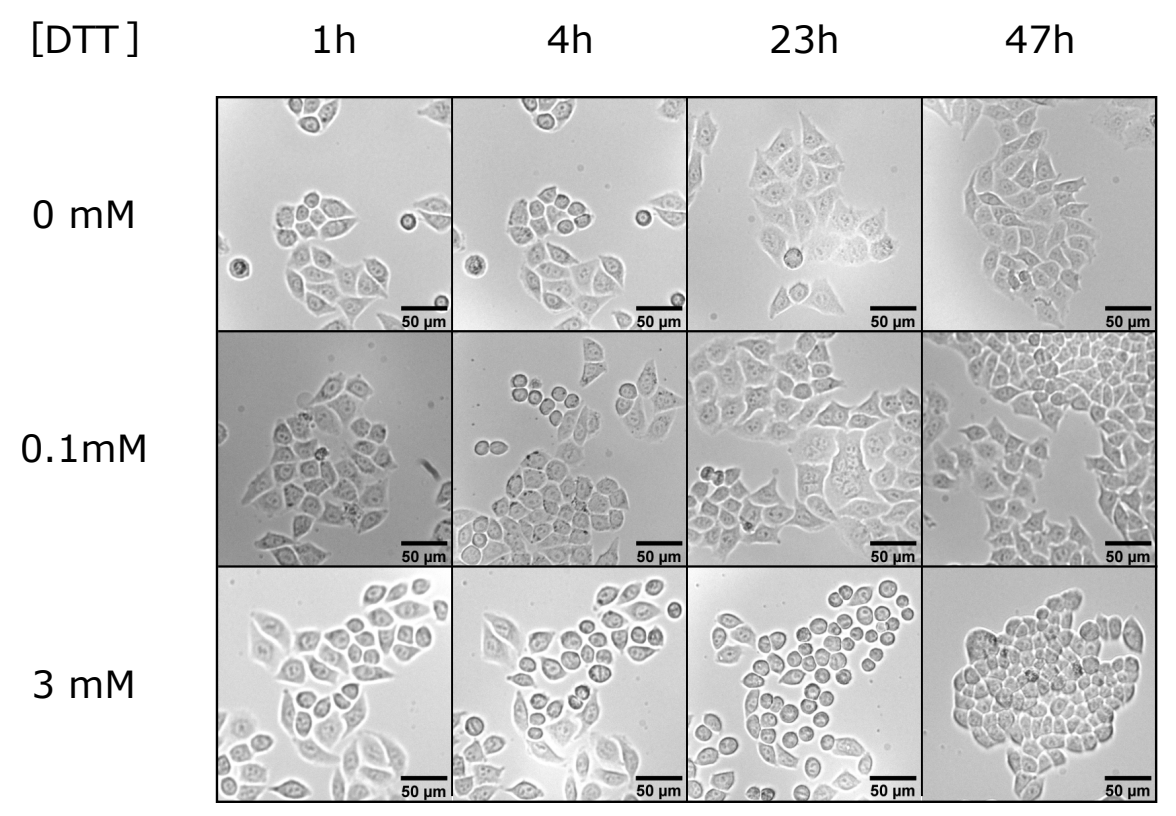

Figure S2: Dithiothreitol (DTT) causes transient cell detachment. Bright-field images at different time points of HeLa cells incubated in $0 \mathrm{mM}, 0.1 \mathrm{mM}$ (used in this study) and 3 $\mathrm{mM}$ (standard PEN reactions) of DTT. Note: images are not always obtained in the same site.

Having identified the cytotoxic components of the PEN DNA toolbox for at least 3 days, we then tested the efficiency of the PEN reactions in the absence of these compounds. To do so, we compared the core element of the PEN reactions, the exponential amplification, at $37^{\circ} \mathrm{C}$, which is the standard temperature for growing human cells. A range in DTT concentration revealed no significant differences in the autocatalytic dynamics (Figure S3a), indicating the possibility of reducing or removing the DTT from the DNA buffer, and hence decrease cellular detachment. For the other cytotoxic component, the PP buffer, we redesigned it but without sodium chloride and ammonium sulphate, from here onwards referred 
as Bio-PP buffer. The autocatalytic network of species $\mathbf{A}$ yielded the expected sigmoidal curve of PEN autocatalysis reactions in both PP buffer and Bio-PP buffer (Figure S3b). An increase in the amplification onset time, $\tau$, from 40 up to $94 \mathrm{~min}$, revealed a slower dynamics between the two buffers. A range of initial concentration of $\mathbf{A}$ in the autocatalytic network further coroborated this, since a $37 \%$ reduction in the rate of the autocatalytic reaction was observed between the PP buffer and the new Bio-PP buffer (Figure S3c). We attributed this reduction mainly to the absence of sodium chloride, which is essential for the efficiency of the enzymes (as specified by supplier). When DMEM was added to the Bio-PP buffer, the rate of the autocatalytic reaction reduced down to 20\% (MT Figure 2a), attributing this to the sodium chloride present in the DMEM. (Note: $\tau$ and rates cannot be directly compared due to the difference in template $\mathbf{T}$ concentration used). The lower fluorescence shift of Bio-PP buffer cannot be easily explained, since it could be a lower trigger production or a difference in fluorescence behaviour of the dye (since salts concentration are important).
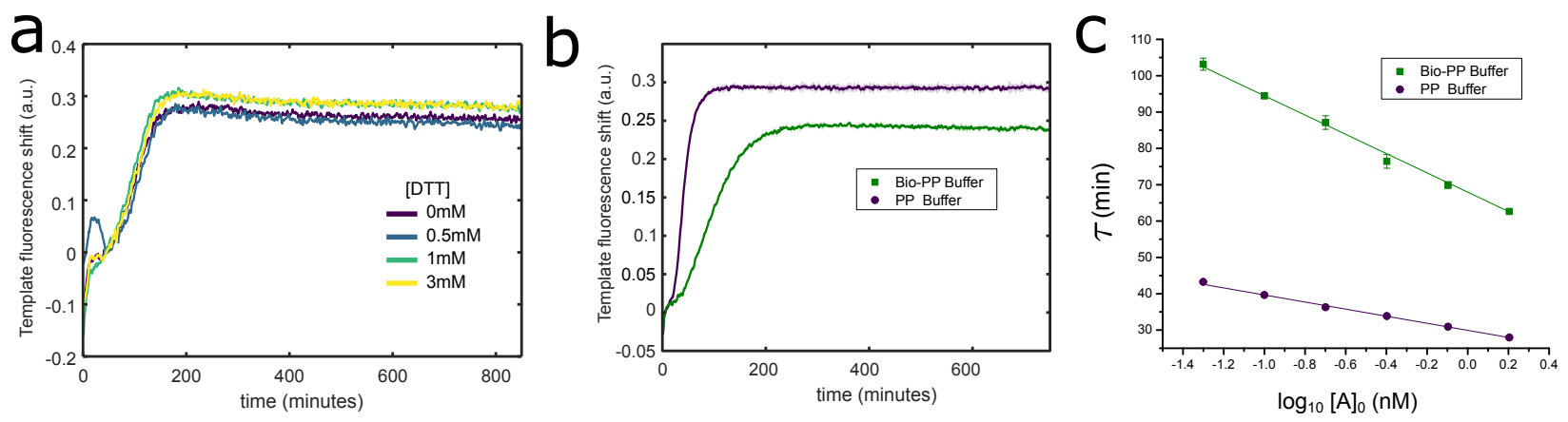

Figure S3: Dynamics of PEN reactions in the absence of cytotoxic compounds. a) Exponential amplification of strand $\mathbf{A}_{1}$ in PP buffer with different DTT concentrations. b) Exponential amplification of strand $\mathbf{A}$ in PP buffer or Bio-PP buffer. The shades, corresponding to the standard deviation of a triplicate experiment, are in the order of 0.01 (a.u), being in the range of the line thickness. c) Amplification onset time, $\tau$, against the decimal logarithm of the initial concentration of $\mathbf{A}$ for the autocatalytic network in PP or Bio-PP buffer. The errors correspond to the standard deviation of a triplicate experiment. Conditions: $50 \mathrm{nM}$ of template, with $1 \mathrm{nM}$ or $0.1 \mathrm{nM}$ trigger for panel a and panel b, respectively.

Having a functional non-cytotoxic PEN reaction, the second step was to make it fully biocompatible to allow the co-existence of living cells. To do this, we had had to add 
the essential cell culture medium, being DMEM and 1\% antibiotics. Figure S4a shows the effect on the PEN dynamics as a function of the DMEM concentration. It can be clearly observed that the higher the concentration of DMEM, the larger the delay of the amplification onset time, and the disappearance of the sigmoidal behaviour. At the highest DMEM concentration tested, $0.66 \mathrm{x}$, a reduction of 5 -fold in the amplification onset time was observed. Implicitly, the higher the DMEM concentration, the closer to cell culture conditions, and hence the higher biocompatibility, but the PEN dynamics were becoming too slow. For this reason, we compromised for a 0.5x DMEM concentration where PEN dynamics was only reduced by 3 -fold. But, before compromising, we verified that the reduction in cell culture concentration was not adverse to cell culture viability. Figure S4b shows that cells presented normal morphology when grown in 0.5x DMEM supplemented with 0.5x PBS (to keep normal osmolarity) for at least 3 days.

To avoid unwanted contamination of the solutions containing cell culture medium, we relied on the use of 1\% Penicillin-Streptomycin antibiotics. Exponential amplification of PEN reactions revealed no significant modification in either standard PP buffer or with further $0.5 \mathrm{x}$ DMEM in the presence or absence of $1 \%$ antibiotics (Figure S4c). To our surprise, when we tested the PP buffer with 0.5x DMEM in the absence of DTT (Figure S4d red dashed line), no autocatalytic behaviour was detected, contrary to what had been previously observed in the absence of DMEM (Figure S3a). This meant that DTT, although been cytotoxic for the cells, needed to be present. When testing a range of DTT in the final optimal biocompatible DNA buffer (Bio-PP buffer, 1\% antibiotics and 0.5x DMEM), we obtained autocatalytic behaviour above $0.2 \mathrm{mM}$ of DTT, with no significant changes in dynamics above this concentration. For this reason, and knowing the cytotoxicity of DTT, the Cell-DNA buffer was defined with $0.1 \mathrm{mM}$ of DTT (Table S1). Biocompatibility and functionality of the Cell-DNA buffer are found in the manuscript. 

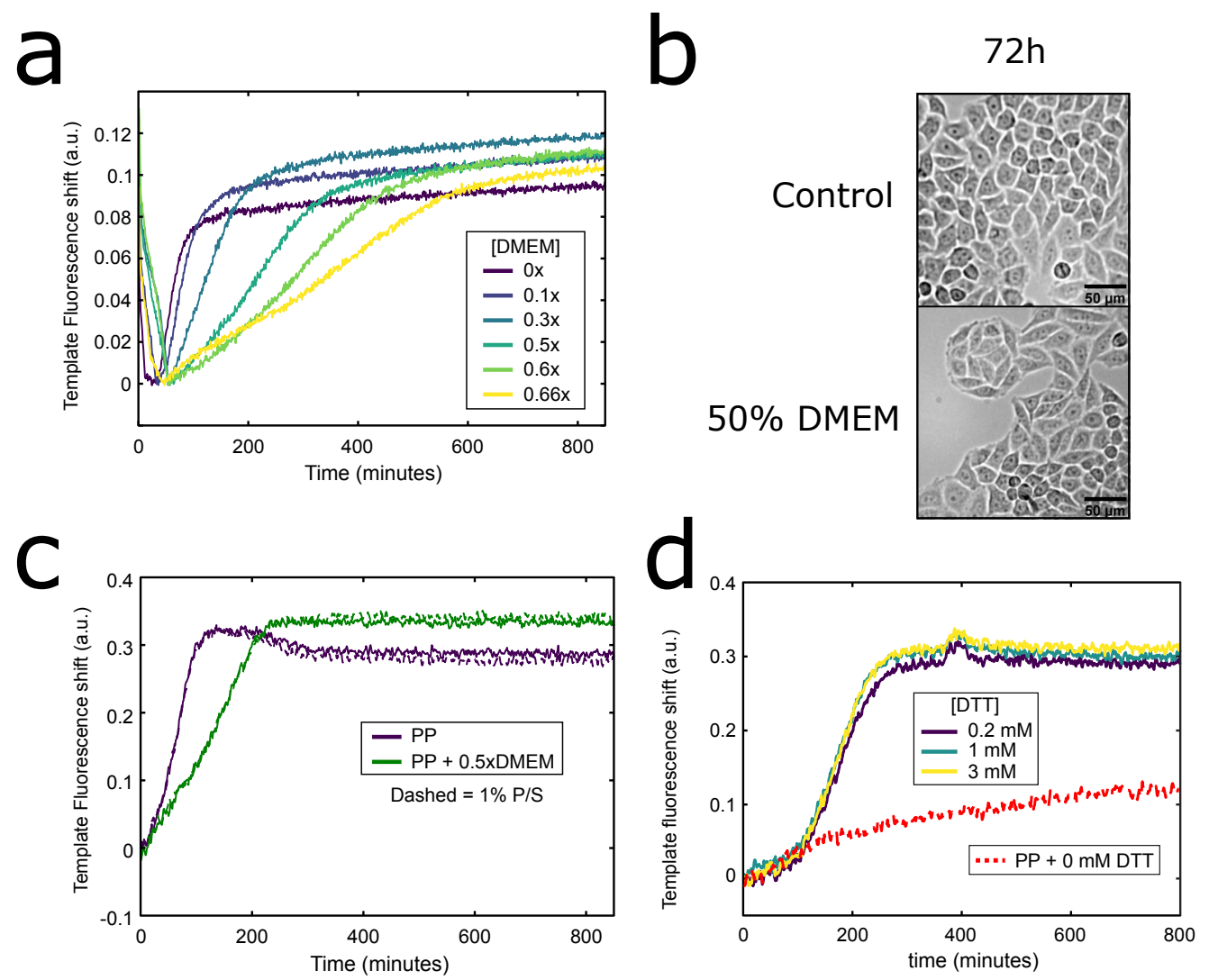

Figure S4: The PEN DNA toolbox works in a biocompatible buffer. a) Exponential amplification of strand $\mathbf{A}_{2}$ in standard DNA buffer (1x) supplemented with different DMEM concentrations. In this case, fluorescent shifts were calculated by normalizing by a late time point $(t=995)$, subtracted from 1 , and shifted vertically to the origin, since raw fluorescence intensities were obtained with the CFX. b) Bright-field images of Hela cells after 71h growing in 0.5x DMEM and 1\% antibiotics (supplemented with 0.5x PBS). c) Exponential amplification of strand $\mathbf{A}_{1}$ in PP buffer (purple line) or in PP buffer with 0.5x DMEM (green line), with (dashed line) or without (solid line) 1\% Penicillin-Streptomycin antibiotics. d) Exponential amplification of strand $\mathbf{A}_{1}$ with 0.5x DMEM in Bio-PP buffer with a range in DTT concentration (solid lines), or in PP buffer without DTT (dashed red line). Conditions: 50 $\mathrm{nM}$ of template, with $1 \mathrm{nM}$ or $0.5 \mathrm{nM}$ trigger for panel a and c, and panel d (except dashed red line which was $1 \mathrm{nM}$ ), respectively. 
3 Tables S1 to S2 
Table S1: Composition of the different buffers used in this work.

\begin{tabular}{|c|c|c|}
\hline Name & Component & Concentration \\
\hline \multicolumn{3}{|l|}{ Cell-DNA buffer } \\
\hline & DTT & $0.1 \mathrm{mM}$ \\
\hline & BSA & $0.125 \mathrm{~g} / \mathrm{l}$ \\
\hline & DMEM & $0.5 \mathrm{x}$ \\
\hline & Antibiotics & $1 \%$ \\
\hline & Bio-PP buffer & $1 \mathrm{X}$ \\
\hline \multicolumn{3}{|l|}{ Bio-PP buffer 1X } \\
\hline & $\mathrm{MgSO}_{4}$ & $6 \mathrm{mM}$ \\
\hline & Syperonic F108 & $0.1 \%$ \\
\hline & dNTPs & $0.4 \mathrm{mM}$ \\
\hline & Netropsin & $2 \mathrm{uM}$ \\
\hline & Bio-Thermopol Buffer & $1 \mathrm{X}$ \\
\hline \multicolumn{3}{|l|}{ Bio-Thermopol buffer 1X } \\
\hline & Tris-HCl & $20 \mathrm{mM}$ \\
\hline & $\mathrm{KCl}$ & $10 \mathrm{mM}$ \\
\hline & MgSO4 & $2 \mathrm{mM}$ \\
\hline \multicolumn{3}{|l|}{ Reference Cell buffer } \\
\hline & Antibiotics & $1 \%$ \\
\hline & DMEM & $99 \%$ \\
\hline \multicolumn{3}{|l|}{ DNA buffer } \\
\hline & DTT & $3 \mathrm{mM}$ \\
\hline & BSA & $0.125 \mathrm{~g} / \mathrm{l}$ \\
\hline & PP buffer & $1 \mathrm{X}$ \\
\hline \multicolumn{3}{|l|}{ PP buffer 1X } \\
\hline & $\mathrm{MgSO}_{4}$ & $6 \mathrm{mM}$ \\
\hline & $\mathrm{NaCl}$ & $50 \mathrm{mM}$ \\
\hline & Synperonic F108 & $0.1 \%$ \\
\hline & dNTPs & $0.4 \mathrm{mM}$ \\
\hline & Netropsin & $2 \mathrm{uM}$ \\
\hline & Thermopol Buffer & $1 \mathrm{X}$ \\
\hline \multicolumn{3}{|l|}{ Thermopol buffer 1X } \\
\hline & Tris-HCl & $20 \mathrm{mM}$ \\
\hline & $\mathrm{KCl}$ & $10 \mathrm{mM}$ \\
\hline & $\mathrm{MgSO}_{4}$ & $2 \mathrm{mM}$ \\
\hline & $\left(\mathrm{NH}_{4}\right)_{2} \mathrm{SO}_{4}$ & $10 \mathrm{mM}$ \\
\hline
\end{tabular}


Table S2: DNA sequences used in this work. Phosphorothioate bonds are marked with an asterisk *, terminal phosphates with p, dual.bt indicates a dual biotin modification, and NH2 indicates Amino C6 modification. JOE, TR (Texas Red), AMCA, DY350, ROX, ATTO590, FAM, Dabcyl (quencher of FAM) and Cy (Cyanine) are the used fluorophores. The name of the species used in the Main Text appears in the left. The corresponding name used internally in the lab, is recalled on the right. Subscript define completely different sequences for the same node (such as templates), while superscript are slight modification of the same sequence (either 5 or 3' chemical modifications, or the addition or subtraction of a nucleotide).

\begin{tabular}{|c|c|c|}
\hline Name & Sequences 5' $\rightarrow 3^{\prime}$ & Lab name \\
\hline A & CATTCTGCGAG & $\mathrm{Ba}-\mathrm{A} 8$ \\
\hline $\mathbf{A}^{1}$ & pCATTCTGCGAG & $\mathrm{pBa}-\mathrm{A} 8$ \\
\hline $\mathrm{T}$ & JOE- ${ }^{*} \mathrm{C}^{*} \mathrm{~T}^{*} \mathrm{C}^{*} \mathrm{GCAGAATGCTCGCAGAAp}$ & JOE_CBa-A8(-2)PS3 \\
\hline $\mathrm{T}^{1}$ & TR- ${ }^{*} \mathrm{C}^{*} \mathrm{~T}^{*} \mathrm{C}^{*}$ GCAGAATGCTCGCAGAAp & TR-CBa-A8-2PS4 \\
\hline $\mathbf{R}$ & $\mathrm{T}^{*} \mathrm{~T}^{*} \mathrm{~T}^{*} \mathrm{TCTCGCAGAATGp}$ & pTBa-A8_T4 \\
\hline $\mathbf{R}^{1}$ & Cy5-T*T*T*TCTCGCAGAATGp & pTBa-A8_T4_Cy5 \\
\hline $\mathbf{S}$ & Cy3.5- ${ }^{*} \mathrm{C}^{*} \mathrm{~T}^{*} \mathrm{~T}^{*} \mathrm{CACCATAACCT}{ }^{*} \mathrm{~A}^{*} \mathrm{C}^{*} \mathrm{C}^{*}-\mathrm{Cy} 3.5$ & Cy3.5_SD1*_Cy3.5 \\
\hline random & САТСТTCATCCСАТСТTСАТСC & $\mathrm{Lp}^{*} \mathrm{Lp}^{*}$ \\
\hline $\mathbf{R}^{*}$ & CATTCTGCGAGAAAA & pTBa-A8_T4* \\
\hline $\mathrm{D}$ & dual.bt-*A*A*G*GTAGGTTATGGTGAAGTCTCGCAGAp & 2Bt_Ba-A8(-3)_2_SD1 \\
\hline $\mathrm{A}-\mathrm{A}$ & CATTCTGCGAGCATTCTGCGAG & $\mathrm{Ba}-\mathrm{A} 8 \_\mathrm{Ba}-\mathrm{A} 8$ \\
\hline $\mathrm{D}^{1}$ & NH2-A*A*G*G*TAGGTTATGGTGAAGTCTCGCAGAp & NH2_Ba-A8(-3)_2_SD1 \\
\hline $\mathrm{D}^{2}$ & NH2-A*A*G*G*TAGGTTATGGTGAAGTCTCGCAGAAp & NH2_Ba-A8(-2)_2_SD1 \\
\hline $\mathbf{A}_{1}$ & CATTCTGACGAG & Ba12 \\
\hline $\mathbf{T}_{1}$ & Cy3.5-* $\mathrm{C}^{*} \mathrm{~T}^{*} \mathrm{C}^{*}$ GTCAGAATGCTCGTCAGAAp & су35-CBa12-2PS4 \\
\hline $\mathbf{A}_{2}$ & CATTCAGGATCG & Be12 \\
\hline $\mathrm{T}_{2}$ & Cy3.5-C*G*A*T*CCTGAATGCGATCCTGAp & cy35-CBe12-3PS4 \\
\hline $\mathrm{F}_{1}$ & AMCA- ${ }^{*} \mathrm{C}^{*} \mathrm{C}^{*} \mathrm{AAGACUCAGCCAAGACTCAGTTTTT}$ & AMCA-e2eT5-B \\
\hline $\mathrm{F}_{2}$ & DY350-*A*A*AAAAAAAAAAAAAAp & DY350-16A \\
\hline $\mathrm{F}_{3}$ & TR- ${ }^{*} \mathrm{C}^{*} \mathrm{~T}^{*} \mathrm{C}^{*} \mathrm{GCAGAATGCTCGCAGAAp}$ & TR-CBa-A8-2PS4 \\
\hline $\mathrm{F}_{4}$ & ROX-CATAACACAATCACA & ROX-Th5,6:6-t \\
\hline $\mathrm{F}_{5}$ & T*T*ACTCAGCTTAGACAGATGACTCTC-ATTO590 & b2ia-AT590 \\
\hline $\mathrm{F}_{6}$ & Cy3-G*T*G*GGAGAATGAAGT-NH2 & Cy3-Li-NH2 \\
\hline $\mathrm{F}_{7}$ & Cy5-*A*A*AAAAAAAAAAAAAAp & Сy5-16A \\
\hline $\mathrm{F}_{8}$ & Cy5.5-A*A*A*AAACAGACUCGAp & Cy5.5pTdA4 \\
\hline ref $_{1}$ & FAM-TCAAGTGAGTCGCAGTCCTCCTTAGCATTCGATCATAAGC-Dabcyl & Nsub \\
\hline $\mathrm{ref}_{2}$ & AGTCTGTTTCGAGTAA & inh16 \\
\hline
\end{tabular}




\section{$4 \quad$ Figures S5 to S14}
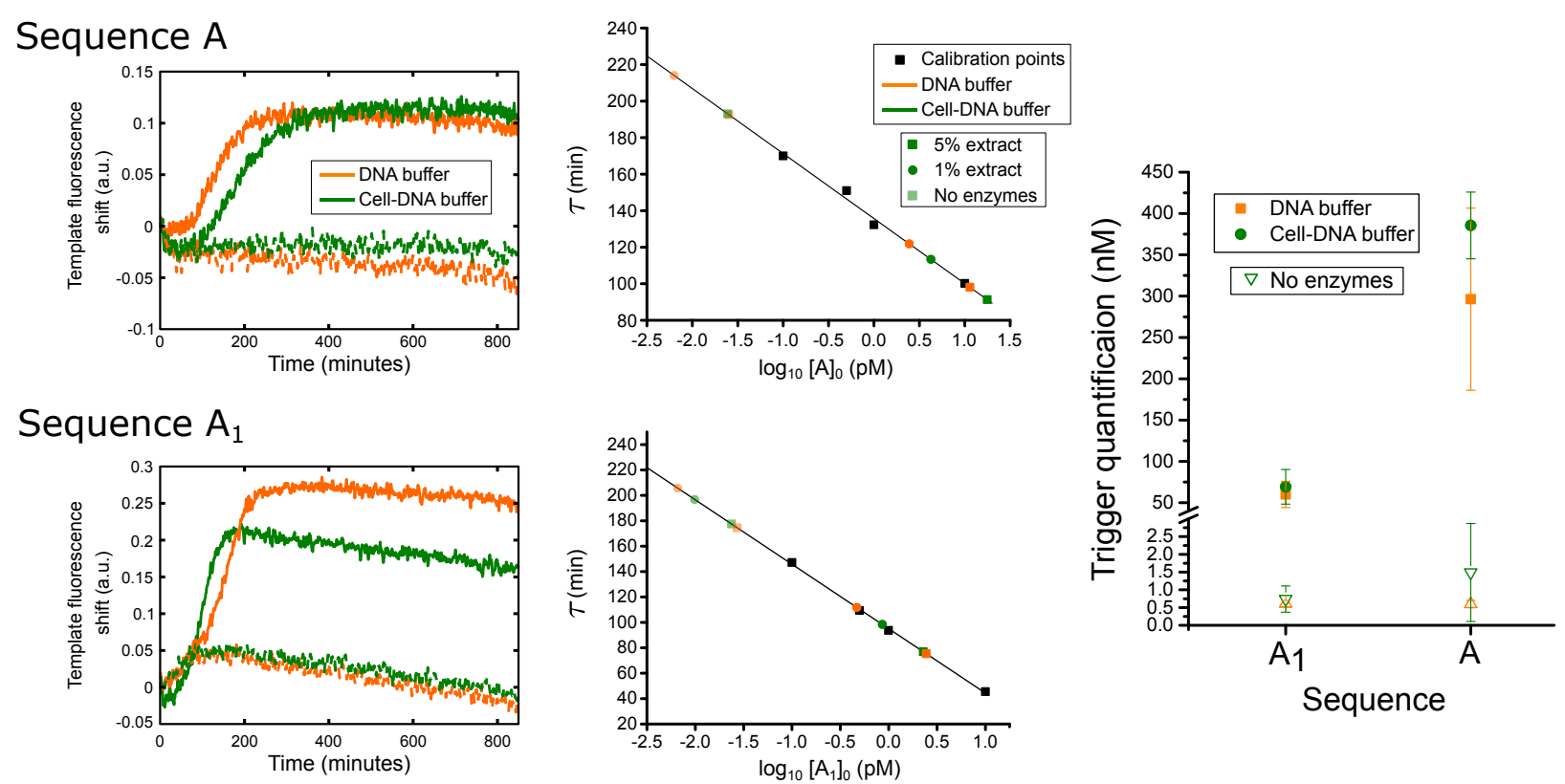

Figure S5: Isothermal quantification of trigger production at steady state for templates $\mathbf{T}^{1}$ and $\mathbf{T}_{1}$ at $37^{\circ} \mathrm{C}$. Left panel shows the exponential amplification from where solution was extracted (5\% or 1\%, square and circle symbol respectively) and placed into a fresh isothermal amplification, where the amplification times, $\tau$, were plotted within a trigger titration calibration curve (middle panel). Right panel shows the extracted trigger concentrations. Trigger concentration of $\mathbf{A}$ is $\sim 10$-fold greater than that of $\mathbf{A}_{1}$ at $37^{\circ} \mathrm{C}$, while little difference between the different buffers is observed. In the case of the negative controls (absence of enzymes), no amplification (or degradation) is expected, hence trigger concentration should be the $[\mathrm{A}]_{0}$ used in the left panel, $0.5 \mathrm{nM}$. Predicted trigger concentrations for the negative controls were in close agreement with the expected, showing the robustness of this technique. 


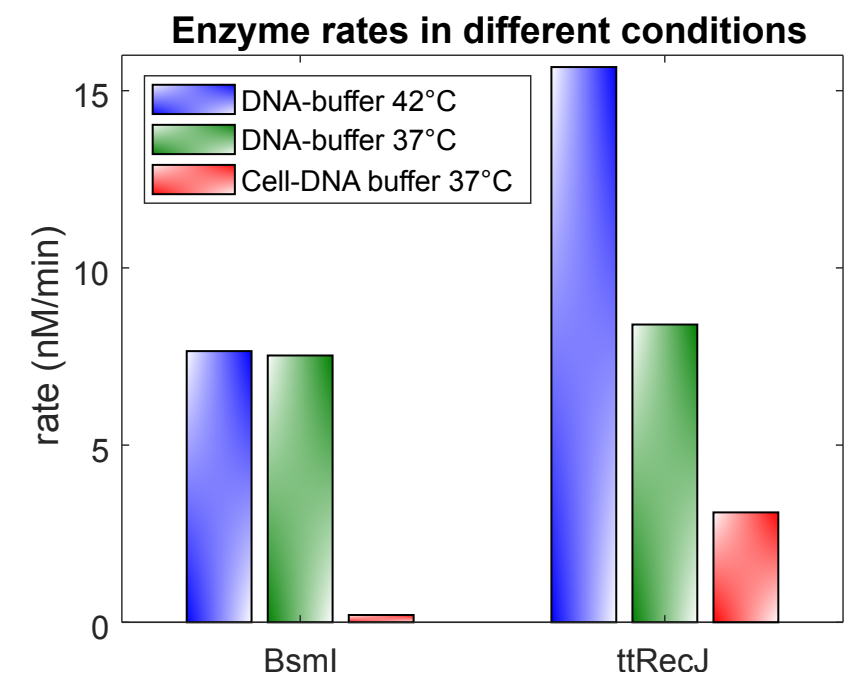

Figure S6: PEN DNA toolbox enzymatic rates measured in different buffers and temperatures. BsmI is the nicking enzymes used for the PEN reaction in the Main Text. ttRecJ is the exonuclease used in the Main text. The rates were measured at different enzyme concentrations: $[\mathrm{BsmI}]=0.4 \%$ and $[\mathrm{ttRecJ}]=1 \%$. 

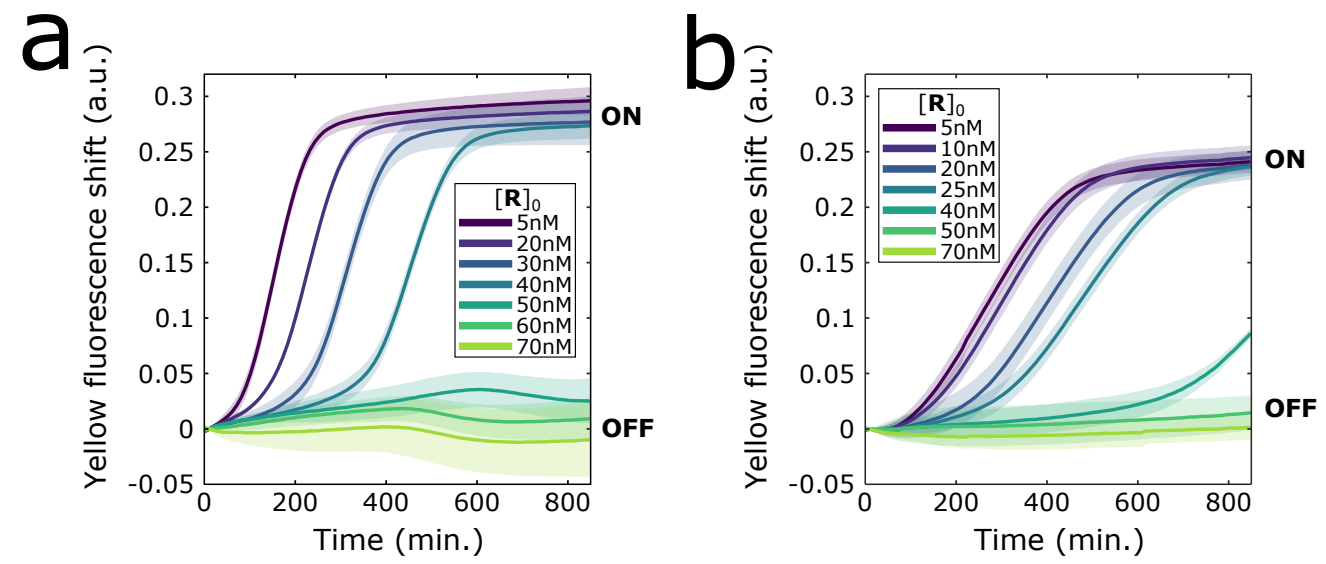

Figure S7: Bistable switch in different buffers associated to MT Figure 2d. Fluorescent shift from fluorescently-labelled $\mathbf{T}$ versus time for the bistable switch for increasing concentrations of $\mathbf{R}$ in standard DNA Buffer (a) and in Cell-DNA buffer in the absence of cells (b). Conditions are identical to MT Figure 2d. 


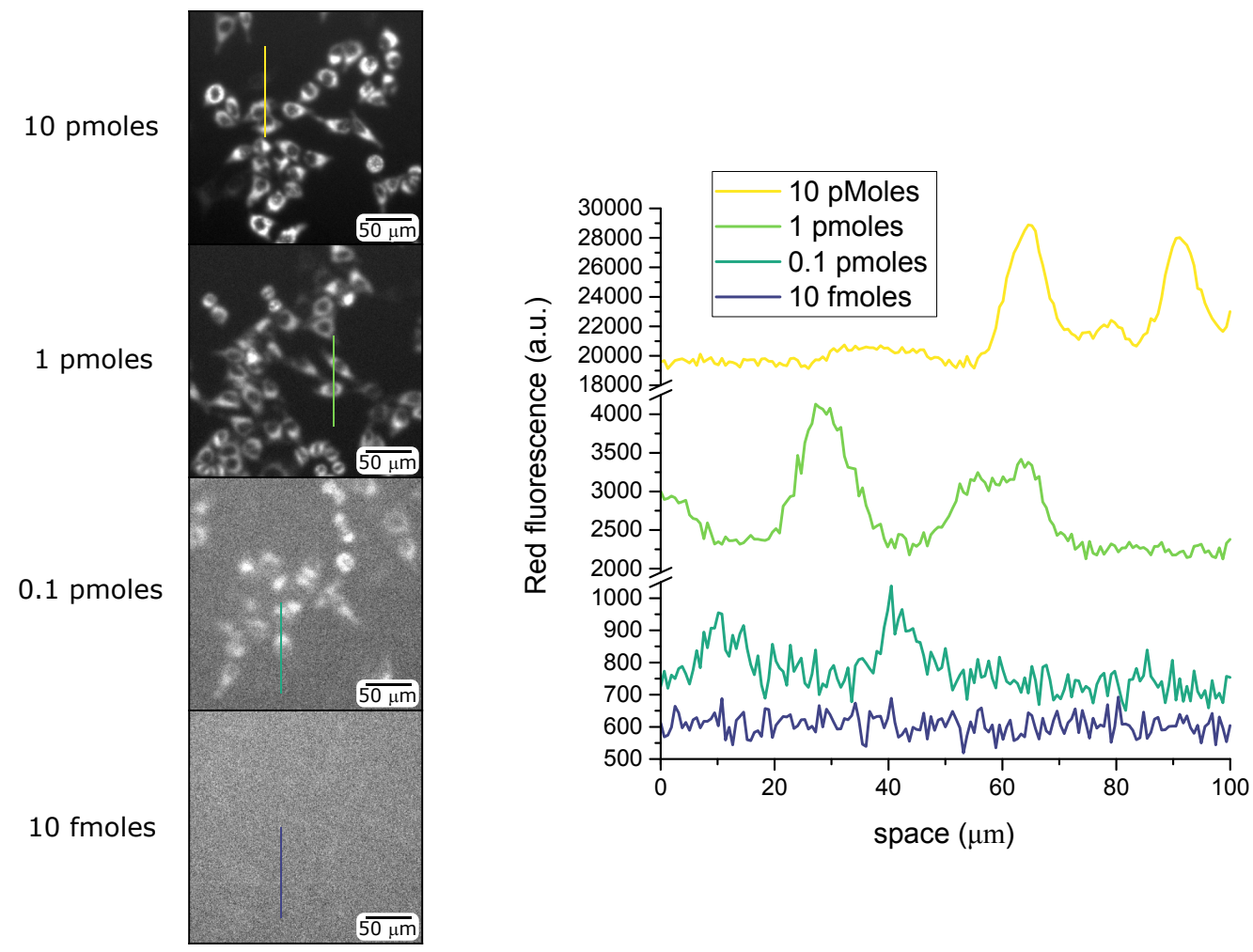

Figure S8: Internalization of Fluorescent DNA. Images of HeLa cells after 10h of incubation with different strand $\mathbf{S}$ concentrations with their respective profiles. Data shows that under 0.1 pmoles of DNA release, no DNA internalization can be distinguished from the background (no rinsing has been performed). Conditions: 2000 cells in 96 cell well plates with $100 \mu \mathrm{L}$ of solution (1\% Penicillin-Streptomycin, Strand S, 2.5\% FBS and DMEM). Image acquisition size $648.1 \mu \mathrm{m}^{2}$. 


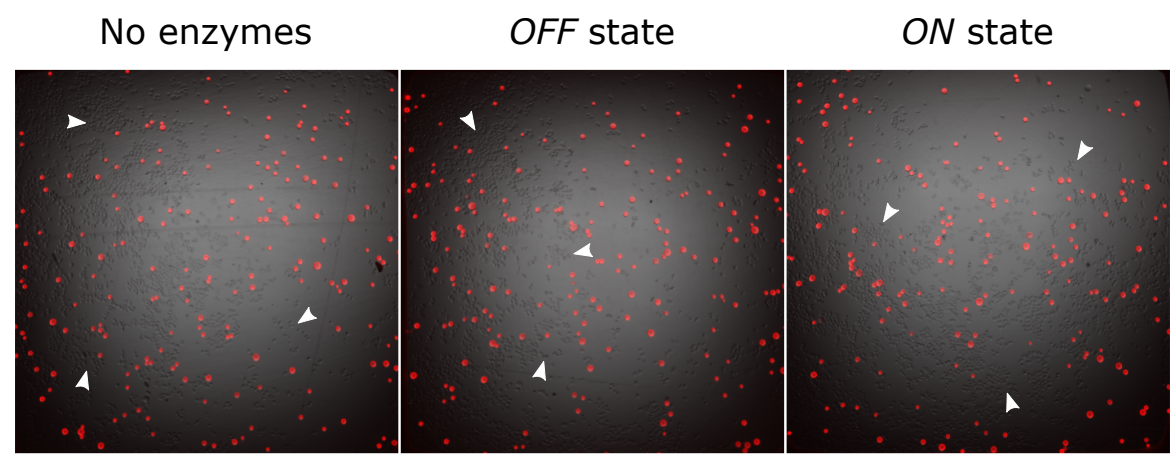

Figure S9: Homogeneity in the distribution of the cells and the conversion beads (in red). Overlapped of bright-field and red fluorescence microscopy images at the start of the experiments shown in MT Figure 3. To calculate \% surface coverage of beads, 'analyze particle' routine of ImageJ was used to extract the number of particles per well, to further calculate using the average particle size provided by the manufacturer, $34 \mu \mathrm{m}$. With 161 particles per well $(n=18)$, a $2.6 \%$ (with a standard deviation of $0.4 \%$ ) surface coverage by the beads was predicted, with a total releasing capacity of $\sim 0.8$ pmoles of Strand $\mathbf{S}$, concentration which should be visible according to Figure S8. Arrowheads are placed to help the visualization of cells. 


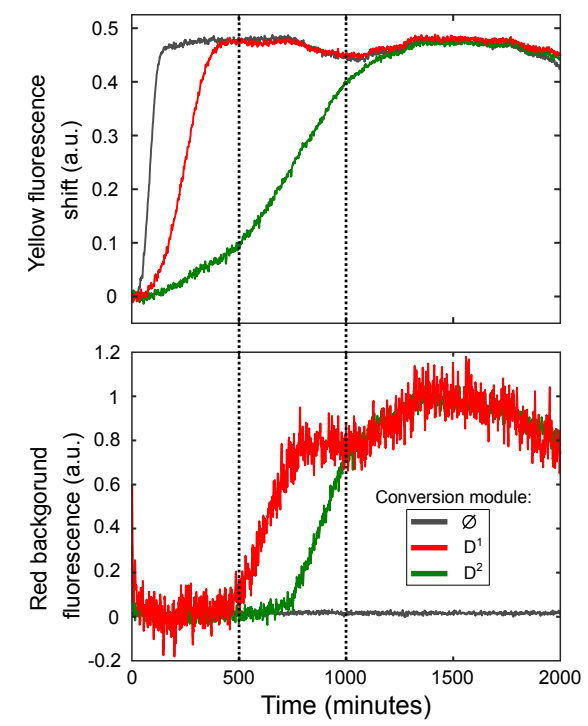

Figure S10: Controlling the release dynamics of strand $\mathbf{S}$. As previously showed by Montagne et al., ${ }^{7}$ strand $\mathbf{A}$ has a higher affinity to $\mathbf{R}$ than to $\mathbf{T}$ because the region of complementarity between $\mathbf{R}$ and $\mathbf{A}$ is larger than that between $\mathbf{T}$ and $\mathbf{A}$ (Table S2). This difference makes the hybridization of $\mathbf{A}: \mathbf{R}$ more thermodynamically stable, and hence predominate, over the $\mathbf{A}: \mathbf{T}$ dsDNA. In the same manner, the conversion module can be tweaked to favour the hybridization A:T over A:D. When the conversion module has the same region of complementarity as that of $\mathbf{T}\left(\mathbf{D}^{2}\right.$, green line), the conversion module slows the exponential amplification by 9 -fold. We account this to the fact that $\mathbf{D}^{1}$ and $\mathbf{T}$ both share $\mathbf{A}$ at low concentrations, which is further corroborated by the fact that both modules finish at relative similar times ( 1000 min). On the other hand, when using a conversion module which has a lower region of complementarity than that of $\mathbf{T}\left(\mathbf{D}^{1}\right.$, red line), the autocatalytic module is only slowed by 3 -fold. In this case, we don't attributed this to the activity of the conversion module, since no release of the load is observed until steady state is reached ( $\sim 500 \mathrm{~min})$. Hence, by reducing the affinity of $\mathbf{A}$ onto $\mathbf{D}$ than that to $\mathbf{T}$, the autocatalytic and the conversion modules finish before, and assures the conversion module is only active when steady state has been reached. $\phi$ is in the absence of conversion module. The black dashed lines are guides to the eye. Conditions: DNA buffer with $50 \mathrm{nM}$ of $\mathbf{T}, 0.5 \mathrm{nM}$ of $[\mathrm{A}]_{0}$, and $20 \mathrm{nM}$ of conversion module $\mathbf{D}^{1}$ or $\mathbf{D}^{2}$ loaded with $15 \mathrm{nM}$ of strand $\mathbf{S}$. Note: we expect no great difference in dynamics due to the presence of dual biotin $(\mathbf{D})$ or Amino C6 $\left(\mathbf{D}^{1}\right.$ and $\left.\mathbf{D}^{2}\right)$. 

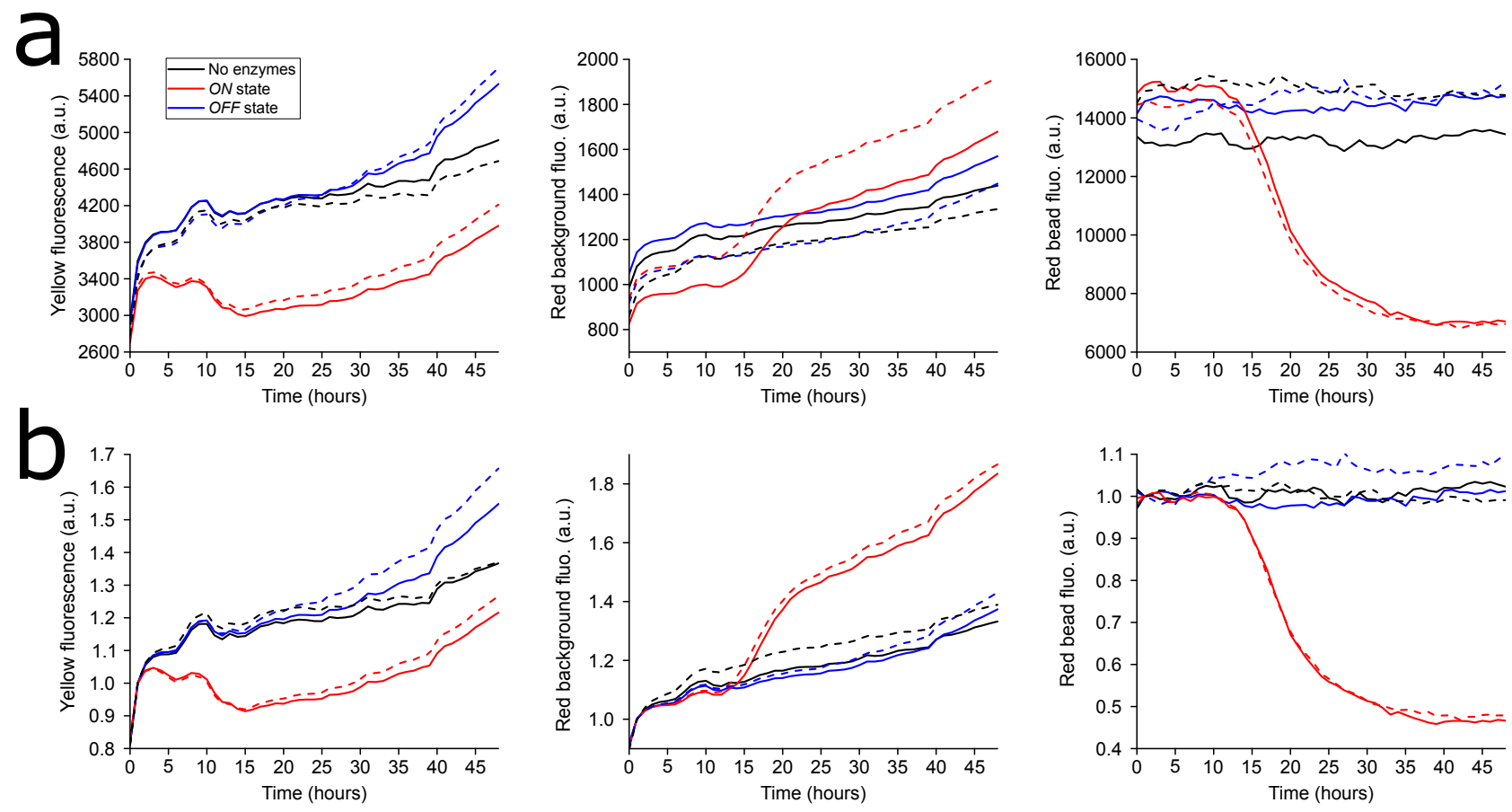

Figure S11: Raw (a) and background-corrected data (b) for one subset of the data presented in MT Figure 3. a) Fluorescence versus time plots displaying the raw data of the internalization switch in the $O N$ (red line) and $O F F$ state (blue line), and in the absence of enzymes (black line) for 2 replicates (full and dashed line) performed the same day. b) Same fluorescence versus time plots as in panel where each curve has been divided by the florescence value at an early time point. We attribute the higher standard error observed in MT Figure 3 compared to panel b, up to 2 orders of magnitude, due to human derived experimental differences between the different experimental days. Conditions are identical to MT Figure 3. 

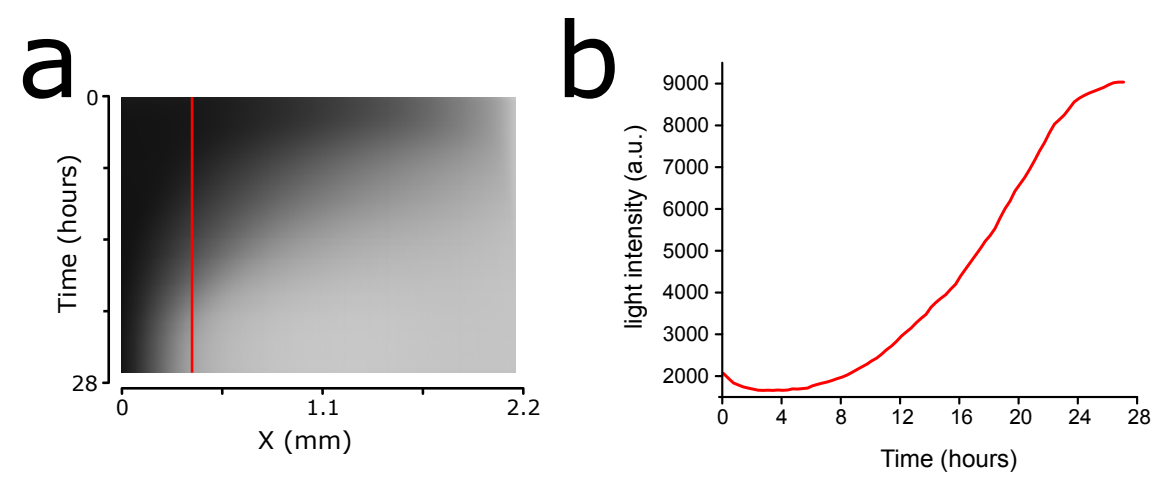

Figure S12: Evaporation dynamics from 384 cell well plates during experimental procedures at $37^{\circ} \mathrm{C}$. a) Kymograph tracking the evaporation of $5 \mu \mathrm{L}$ of DMEM medium in a 384 cell well plate over time. Note that $5 \mu \mathrm{L}$ is not sufficient to wet the entire bottom of the well (spatial heterogeneity). b) Profile depicted in panel a. As the DMEM medium evaporates, the light intensity of the well increases until it reaches saturation, where no more changes in the light path occur. An evaporation rate of $4.44 \mu \mathrm{L} /$ day is foreseen to occur in our setup, giving rise to a maximal total loss of $27 \%$ during 2 days. As volume in the 384 cell well plate decreases. the concentration of the fluorescently-labelled $\mathbf{T}$ increases, and so does its fluorescence signal. Since the yellow fluorescence shift graphs depict the quenching phenomenon of the fluorophore, the increase in the fluorescence due to evaporation transduced into a decrease in the yellow fluorescence shift (observed in MT Figure 3 and 4). 

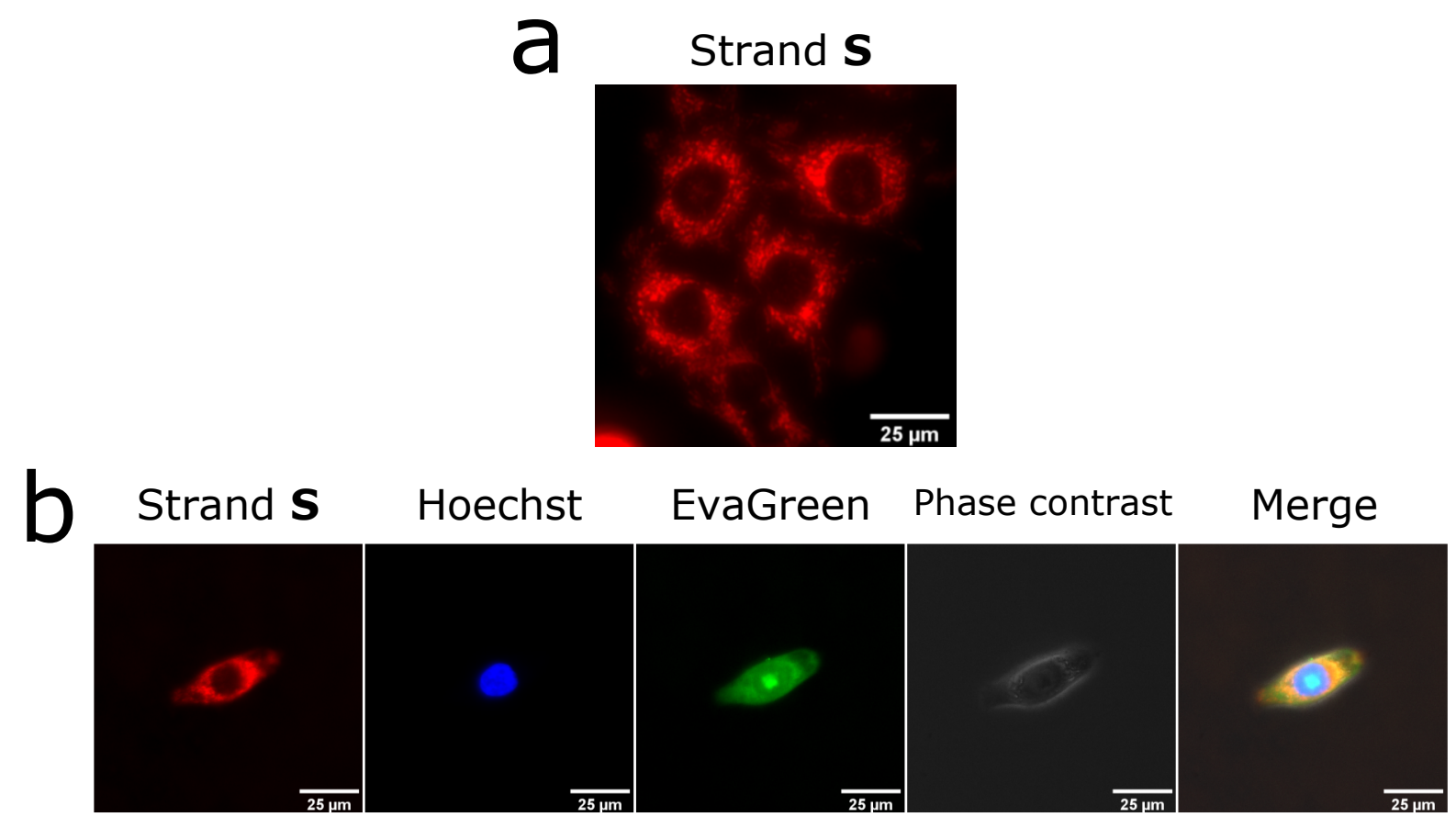

Figure S13: Strand S internalizes into dot and rod-like compartments. a) Dried cell images showing the spatial distribution of strand $\mathbf{S}$ into rod-like compartments. b) Imaging of living cells in the presence of the strand $\mathbf{S}$, a nuclear staining (Hoechst), EvaGreen (which resulted in the staining of the membrane and partially of the inner nucleus) and phase contrast. The merge reveals strand $\mathbf{S}$ is not evenly distributed within the cytoplasm, but rather focused closely to the nucleus of the cell. Images obtained with a 40X objective. Image acquisition size $166.4 \mu \mathrm{m}^{2}$ and $332.8 \mu \mathrm{m}^{2}$ for the top and bottom panel, respectively. 

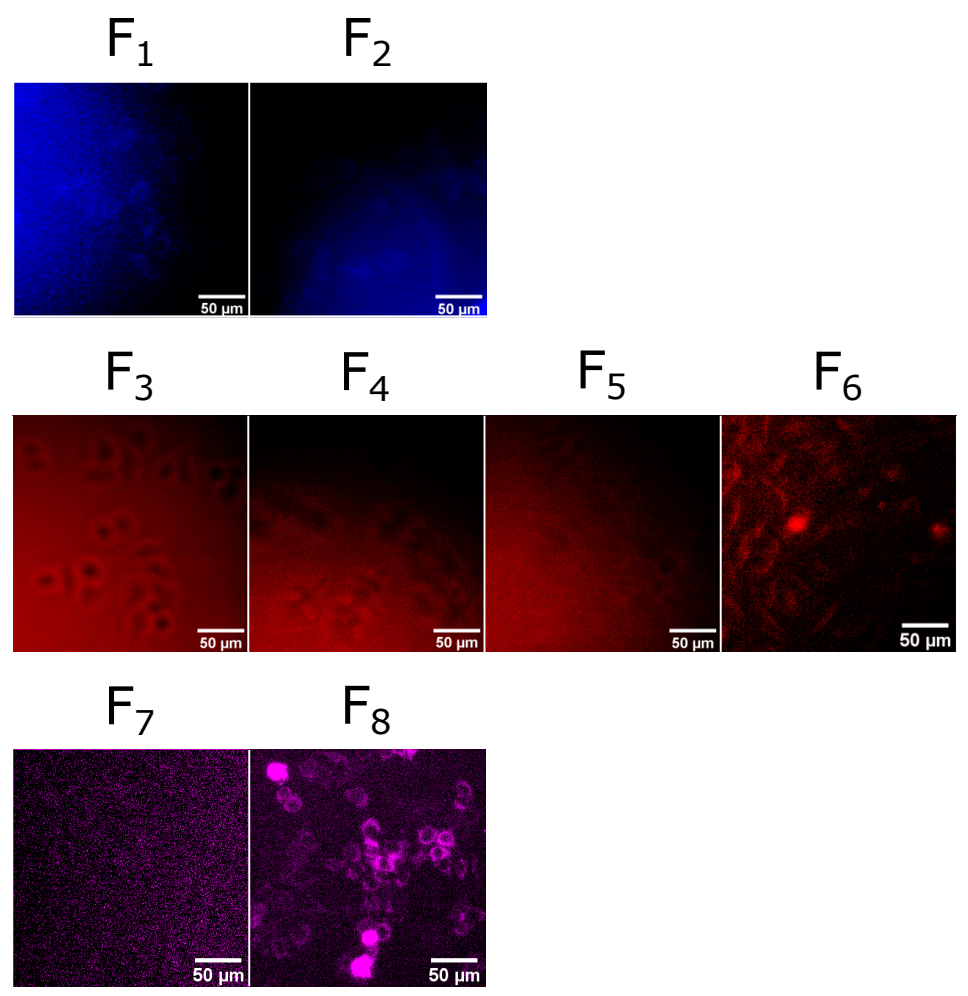

Figure S14: Detection capabilities of other standard DNA-fluorescent markers. Due to different molecular structures, some standard DNA-fluorescent markers may not be internalized or do not show fluorescence upon internalization. We screened the detection capabilities of different fluorescently labelled strands $\left(\mathrm{F}_{1}-\mathrm{F}_{8}\right)$ after $24 \mathrm{~h}$ of incubation in the presence of living HeLa cells. In addition to the marker used in this manuscript (Cyanine3.5), we only observed internalized fluorescence for Cyanine5.5 markers $\left(\mathrm{F}_{8}\right)$. We observed difference in behaviours within the same family of fluorescent markers, since we didn't detect internalization for Cyanine $3\left(\mathrm{~F}_{6}\right)$ or Cyanine $5\left(\mathrm{~F}_{7}\right)$, which present very small structural differences. Conditions: 1 pMoles of each strand was added to a final volume of $50 \mathrm{ul}$ or $100 \mathrm{ul}$ for 384 or 96 cell well plates with 3200 or 1600 cells per well, respectively. Blue, red and far-red filters were used for the top, middle and bottom panel, respectively. Note: The internalization of the different fluorophores was tested with different sequences bearing or not PTO, and terminal-phosphate modification, which could influence also the internalization yield. 


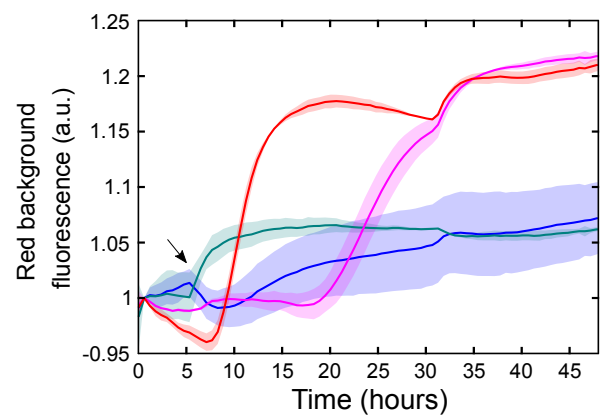

Figure S15: Release of the load $\mathbf{S}$ into the medium by the response of the internalization switch in MT Figure 4a and b. Fluorescence versus time plots displaying the dynamics release into the solution in the $O N$ (red line) and $O F F$ (blue line) states, as well as $O F F$ states where a ssDNA, either $\mathbf{R}^{*}$ (pink) or a random sequence (teal), which were introduced at $\mathrm{t}=6 \mathrm{~h}$ (indicated with an arrow). The bump at $t=6 \mathrm{~h}$ is an artifact resulting from the addition of the ssDNA. Conditions are identical to MT Figure 4a and b. 


\begin{tabular}{|c|c|c|}
\cline { 2 - 3 } \multicolumn{1}{c|}{} & {$[\mathrm{A}]_{0}$} & {$[\mathrm{R}]_{0}$} \\
\hline & $20 \mathrm{nM}$ & $0 \mathrm{nM}$ \\
\hline & $0 \mathrm{nM}$ & $0 \mathrm{nM}$ \\
\hline & $0 \mathrm{nM}$ & $10 \mathrm{nM}$ \\
\hline & $20 \mathrm{nM}$ & $200 \mathrm{nM}$ \\
\hline
\end{tabular}
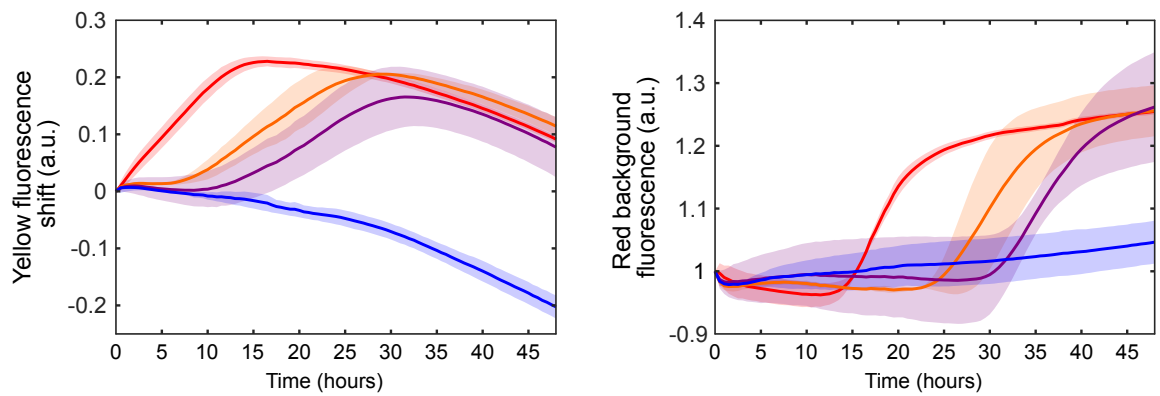

Figure S16: Pre-programmed temporal release of the load $\mathbf{S}$ into the medium. Release of the load $\mathbf{S}$ into the medium by the response of the internalization switch in MT Figure 4c and d. Fluorescence versus time plots displaying the dynamics of production of $\mathbf{A}$ (left) and the release of $\mathbf{S}$ into the solution (right) in the presence of cells with different initial conditions. The $O N$ and the $O F F$ states are represented by the red and the blue conditions, respectively, while in the absence of initial trigger and in the presence of low $\mathbf{R}$ are represented by the orange and the purple conditions, respectively. A delay on the exponential amplification is observed due to the absence of initial trigger, compared to the $O N$ state. This delay is further increased in the presence of $10 \mathrm{nM}$ of $\mathbf{R}$, where at high concentration of $\mathbf{R}$ (OFF state), the exponential amplification never occurs. The delay on the exponential amplification is transferred into a systematic delay of the release of $\mathbf{S}$ into the solution. Conditions are identical to MT Figure 4c and d. 

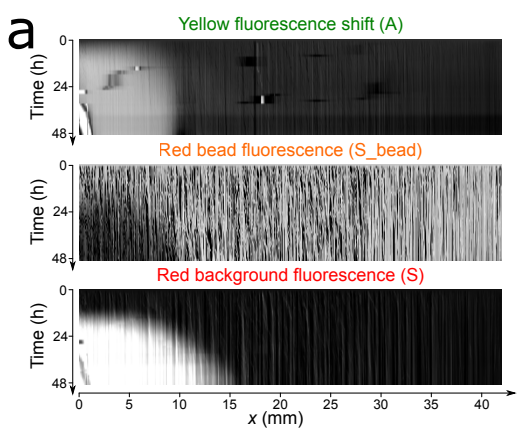
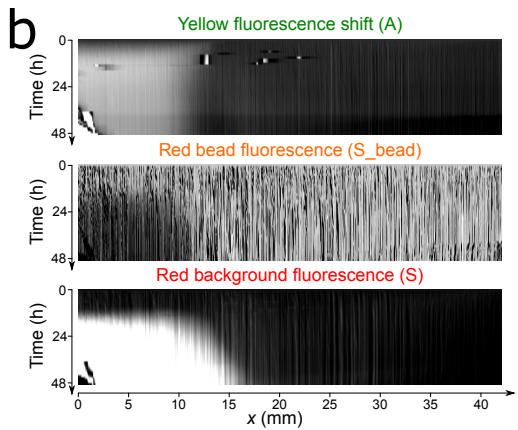
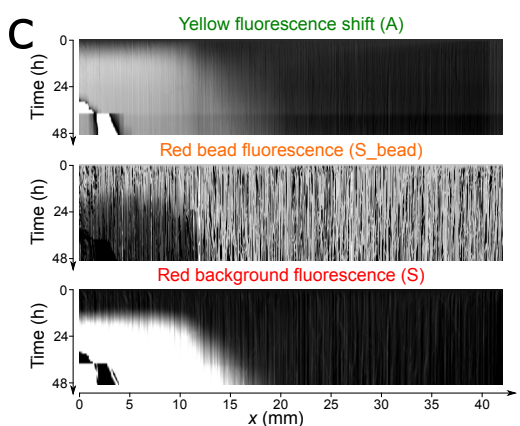

Figure S17: Spatiotemporal dynamics of the internalization switch in the absence of cells. a) Kymographs representing the behaviour of the autocatalyst, yellow fluorescence shift (A), the Red bead fluorescence (S_bead), and of the Red background fluorescence (S) with a gradient of repressor $(\mathbf{R})$ performed with $65 \mu \mathrm{L}$ as the injecting volume. b) idem to panel a but using $55 \mu \mathrm{L}, 10 \mu \mathrm{M}$ of $\mathbf{R}$ and pipetting back and forth 4 times instead of 5 to generate the gradient. c) idem to panel b but using $2 \mu \mathrm{M}$ of $\mathbf{R}$. 

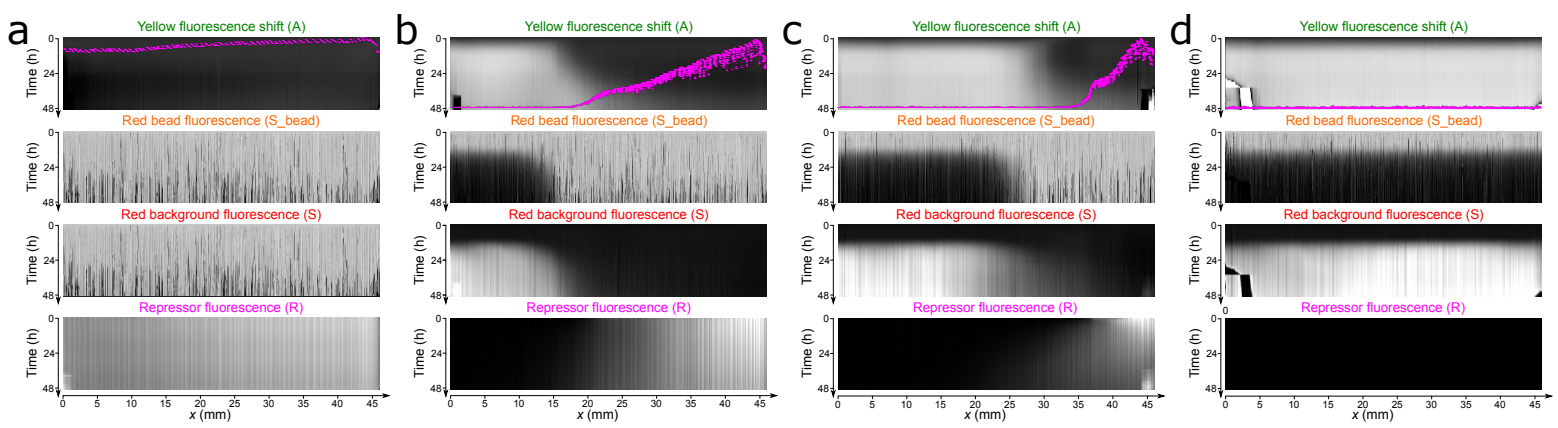

Figure S18: Spatiotemporal dynamics of the different repressor $(\mathbf{R})$ patterns shown if MT Figure $5 \mathrm{f}$-g. a) Kymographs representing the behaviour of the autocatalyst, yellow fluorescence shift (A), the Red bead fluorescence (S_bead), the Red background fluorescence (S) and the Repressor fluorescence (R) starting with a high concentration of $\mathbf{R}$ (OFF state). b) Kymographs showing the spatiotemporal behaviour in the presence of a gradient of $\mathbf{R}$ performed using $55 \mu \mathrm{l}$ as the injecting volume. c) Idem to panel b but in the presence of a gradient of $\mathbf{R}$ performed using $25 \mu \mathrm{l}$ as the injecting volume. d) Idem to panel a but in the absence of $\mathbf{R}$ ( $O N$ state). The magenta line over-imposing the yellow fluorescence shift kymographs represents the initial $\mathbf{R}$ pattern $(t=0 \mathrm{~h})$. Panels a and $\mathrm{d}$ show the raw fluorescence of $\mathbf{R}$, while in panels $\mathrm{b}$ and $\mathrm{c}$ the fluorescence has been normalized between 0 and 1. Conditions are identical to MT Figure 5. 


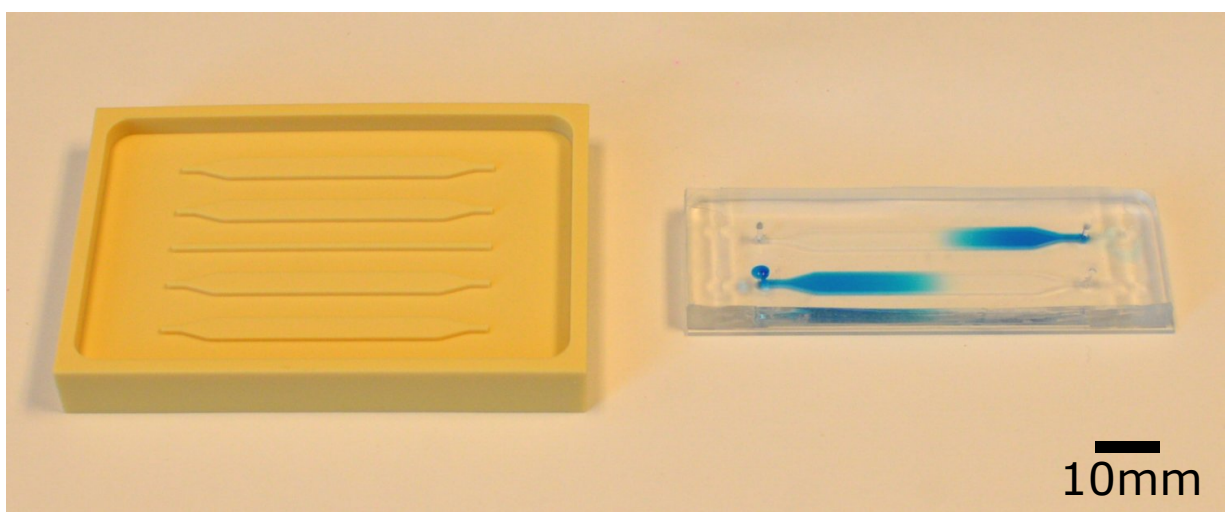

Figure S19: Mold and millifluidic device used for experiments in MT Fig. 5. Left: reusable polyvinyl chloride (PVC) mold fabricated using a milling machine. Right: millifluidic device made of molding poly(dimethylsiloxane) and sticking it on a glass slide. The channels are $50 \mathrm{~mm}$ long, $3 \mathrm{~mm}$ wide and $1 \mathrm{~mm}$ high. Here, a 2-channel device with two gradients of methylene blue dye is shown. 


\section{$5 \quad$ Video $\mathrm{S} 1$}

Video S1: Timelapse showing the internalization of fluorescently-labelled DNA (strand $\mathbf{S}$ ) by HeLa cells in under 4h. Conditions: 1 pmoles experiment of Figure S8. 


\section{References}

1. Zadorin, A. S., Rondelez, Y., Gines, G., Dilhas, V., Urtel, G., Zambrano, A., Galas, J. C., and Estevez-Torres, A. (2017) Synthesis and Materialization of a Reaction-Diffusion French Flag Pattern. Nature Chemistry 9, 990-996.

2. Montagne, K., Plasson, R., Sakai, Y., Fujii, T., and Rondelez, Y. (2011) Programming an in Vitro DNA Oscillator Using a Molecular Networking Strategy. Mol Syst Biol \%, 466, 10.1038/msb.2010.120.

3. Baccouche, A., Montagne, K., Padirac, A., Fujii, T., and Rondelez, Y. (2014) Dynamic DNA-Toolbox Reaction Circuits: A Walkthrough. Methods 67, 234-249.

4. Urtel, G., Van Der Hofstadt, M., Galas, J. C., and Estevez-Torres, A. (2019) rEXPAR: An Isothermal Amplification Scheme that is Robust to Autocatalytic Parasites. Biochemistry $58,2675-2681$.

5. Owczarzy, R., Moreira, B. G., You, Y., Behlke, M. A., and Walder, J. A. (2008) Predicting Stability of DNA Duplexes in Solutions Containing Magnesium and Monovalent Cations. Biochemistry 47, 5336-5353.

6. Held, K. D., Sylvester, F. C., Hopcia, K. L., and Biaglow, J. E. (1996) Role of Fenton Chemistry in Thiol-Induced Toxicity and Apoptosis. Radiation Research 145, 542-553.

7. Montagne, K., Gines, G., Fujii, T., and Rondelez, Y. (2016) Boosting Functionality of Synthetic DNA Circuits with Tailored Deactivation. Nature Communications 7, 13474. 